\title{
"Hybrid Rulemaking" under the Administrative Procedure Act: A Legal and Empirical Analysis*
}

\author{
Stephen F. Williams $\dagger$
}

By its terms the Administrative Procedure Act ${ }^{1}$ (APA) divides all rulemaking by federal agencies into two categories: "informal" or "notice-and-comment" rulemaking under section 553, and "formal" or "on-the-record" rulemaking under sections 556 and 557. An agency must use formal rulemaking when "rules are required by statute to be made on the record after opportunity for an agency hearing." In such instances rules must be supported by substantial evidence in the "record." 3 In addition, parties to the proceeding are entitled to "conduct such cross-examination as may be required for a full and true disclosure of the facts," although this may be curtailed when a party will not "be prejudiced thereby." In noticeand-comment rulemaking, by contrast, there is no requirement that the rule be based upon evidence in a record. ${ }^{5}$ And section 553

* This paper is the outgrowth of work I undertook as a consultant to the Committee on Judicial Review of the Administrative Conference of the United States. Neither the Conference nor the Committee has approved this paper, but recommendations deriving from the study have been approved by the Committee on Judicial Review. I am indebted to the chairman of the Committee on Judicial Review, William H. Allen, to William F. Pedersen, and to my colleague Alfred T. McDonnell, for innumerable constructive suggestions.

$\dagger$ Associate Professor of Law, University of Colorado.

'5 U.S.C. $\$ \$ 551-706(1970)$.

2 Id. $\S 553(\mathrm{c})$.

3 See id. $\$ 706(2)(\mathrm{E})$.

+ Id. § 556(d).

s California Citizens Band Ass'n v. United States, 375 F.2d 43, 54 (9th Cir.), cert. denied, 389 U.S. 844 (1967). But see, e.g., cases cited at notes 7-8 infra; cf. Citizens to Preserve Overton Park, Inc. v. Volpe, 401 U.S. 402, 414-15 (1971). 
does not mention cross-examination: an agency need only afford "interested persons an opportunity to participate in the rule making through submission of written data, views, or arguments with or without opportunity for oral presentation." 6

This article deals with several recent judicial decisions that have ordered an agency-despite the inapplicability of sections 556 and 557-to afford opponents of a rule substantially greater procedural opportunities than are prescribed by section 553 . The challenging parties in these cases have successfully asserted two distinct types of rights: first, a somewhat qualified right of crossexamination $;^{7}$ and second, a right of access to details of the agency's methodology, thus permitting that methodology to be subjected to meaningful criticism. ${ }^{8}$ None of these cases relied on the APA's procedural requirements concerning formal rulemaking; ${ }^{9}$ indeed, several of the opinions showed no inclination to rule that the particular decision-making process in contention fell anywhere within APA classifications. ${ }^{10}$ Thus, with only a little help from Congress, the courts seem to have created a procedural category that might be termed "hybrid rulemaking" or "notice-and-comment-plus."

This article has several purposes: first, to explore in a general way the differences between fact-finding used for promulgating a

65 U.S.C. $\$ 553(\mathrm{c})(1970)$.

7 International Harvester Corp. v. Ruckelshaus, 478 F.2d 615, 629-31, 649 (D.C. Cir. 1973); Appalachian Power Co. v. EPA, 477 F.2d 495, 503 (4th Cir. 1973); Walter Holm \& Co. v. Hardin, 449 F.2d 1009, 1016 (D.C. Cir. 1971); Mobil Oil Corp. v. FPC, 483 F.2d 1238, 1260 (D.C. Cir. 1973) (semble) (requiring "the process of testing and illumination ordinarily associated with adversary, adjudicative procedures").

${ }^{8}$ Public Serv. Comm'n v. FPC, 487 F.2d 1043, 1071, 1098 (D.C. Cir. 1973), vacated and remanded, 417 U.S. 964 (1974); Portland Cement Ass'n v. Ruckelshaus, 486 F.2d 375, 402 (D.C. Cir. 1973), cert. denied, 417 U.S. 921 (1974); Mobil Oil Corp. v. FPC, 483 F.2d 1238, 1260, 1268 (D.C. Cir. 1973) (semble); International Harvester Corp. v. Ruckelshaus, 478 F.2d 615,649 (D.C. Cir. 1973).

See, e.g., Mobil Oil Corp. v. FPC, 483 F.2d 1238, 1250-51 (D.C. Cir. 1973) (denying that formal rulemaking requirements applied); International Harvester Corp. v. Ruckelshaus, 478 F.2d 615, 630 n.48 (D.C. Cir. 1973) (same).

${ }^{10}$ In Appalachian Power Co. v. EPA, 477 F.2d 495 (4th Cir. 1973), the Fourth Circuit declared:

It is idle, and fruitless, to boggle over the appropriate classification of the Administrator's action, though we cannot avoid observing that the Administrator, in his order of approval, described his action as "rulemaking". Modern precedent has discarded such classifications as criteria for determining the type of hearing to which the parties affected by administrative action are entitled . . . .

Id. at 500. See also Public Serv. Comm'n v. FPC, 487 F.2d 1043, 1069 (D.C. Cir. 1973), vacated and remanded, 417 U.S. 964 (1974) (declining to reach the problem of classifying); Walter Holm \& Co. v. Hardin, 449 F.2d 1009 (D.C. Cir. 1971) (ignoring the issue). But see Portland Cement Ass'n v. Ruckelshaus, 486 F.2d 375, 393 n.67 (D.C. Cir. 1973), cert. denied, 417 U.S. 921 (1974) (identifying the rulemaking as informal). 
rule and fact-finding used for applying a pre-existing rule; second, to consider under what legal theories, and in what circumstances, a court may be justified in imposing procedural burdens upon an agency engaged in rulemaking; third, to describe how selected cases $^{11}$ have actually influenced the agencies involved, and to assess empirically the effectiveness and costs of the procedures prescribed; and, finally, to suggest some considerations that might bear on the propriety of similar judicial intervention in the future.

\section{Prologue: The Distinctive Nature of Fact-Finding for the Purpose of Promulgating Rules}

A misunderstanding of the facts can be as unfortunate in developing a rule of law as in determining whether defendant breached his contractual duty to plaintiff. Lochner $v$. New York ${ }^{12}$ is a classic instance. Without any detailed factual inquiry, and without any serious review of the legislature's factual inquiry, the Court resolved the constitutionality of a statute limiting the working hours of bakers; an apparently crucial part of its decision was an empirical assertion about whether work in a bakery posed significant risks to the bakers' health. ${ }^{13}$

Yet courts have rarely intervened to assure that parties adversely affected by administrative rulemaking will have an adequate opportunity to challenge the factual assumptions underlying the rules. This judicial reluctance may be explained by the differences in the institutional setting and intellectual processes that are involved in fact resolution for rulemaking purposes, on the one hand, and for adjudicative purposes, on the other.

Justice Holmes's opinion in Bi-Metallic Investment Co. $v$. State Board of Equalization ${ }^{14}$ is the most salient intellectual antecedent of "informal" rulemaking procedures, and it focuses directly on the institutional setting. On the theory that tax assessments in Denver were, as a whole, radically lower than assessments in the remainder of Colorado, the State Board of Equalization and the Colorado Tax Commission had ordered an across-the-board increase of forty percent in valuations of taxable property in Denver. The Supreme Court held that the plaintiff, a Denver taxpayer, had no right to a hearing before either state agency. Holmes wrote:

\footnotetext{
" Cases cited notes 7-8 supra.

12198 U.S. 45 (1905).

13 Id. at 59 .

14239 U.S. 441 (1915).
} 
Where a rule of conduct applies to more than a few people it is impracticable that every one should have a direct voice in its adoption. The Constitution does not require all public acts to be done in town meeting or an assembly of the whole. General statutes within the state power are passed that affect the person or property of individuals, sometimes to the point of ruin, without giving them a chance to be heard. Their rights are protected in the only way that they can be in a complex society, by their power, immediate or remote, over those who make the rule..$^{15}$

In its assumption that a "hearing" is infeasible when the interests of many people are at stake, the argument is inadequate on its face. Of course each person affected by a general rule cannot individually enjoy the type of hearing associated with adjudication. But an agency can nevertheless permit a suitable champion to represent the entire group (or each of several conflicting interest groups). Class actions are and always have been built upon the feasibility of such techniques. ${ }^{16}$ And in recent times the concept of representation has been used to justify relaxing the prerequisites of standing to sue administrative agencies. ${ }^{17}$

A second dimension to Justice Holmes's concern about the numbers affected is more plausible: the possibly greater utility of the political process as a check upon administrative error. When a single citizen is the victim of an erroneous adjudicative decision the prospect of political relief is remote. With an increase in the number of persons adversely affected, the chance of political relief may, ceteris paribus, rise proportionately. Recent history gives some support to Justice Holmes's assumption. Just in the past year, two regulations originally promulgated in the interests of health and safety-Environmental Protection Agency (EPA) rules calling for

15 Id. at 445.

is See, e.g., Supreme Tribe of Ben-Hur v. Cauble, 255 U.S. 356 (1921); Smith v. Swormstedt, 57 U.S. (16 How.) 288 (1853); Hichens v. Congreve, 4 Russ. 562, 38 Eng. Rep. 917 (Ch. 1828); Good v. Blewitt, 13 Ves. Jun. 397, 33 Eng. Rep. 343 (Ch. 1807); Chancey v. May, Prec. Ch. 592, 24 Eng. Rep. 265 (Ch. 1722). In Bi-Metallic itself, the Denver assessor was available as such a champion; having been joined in the suit, he objected to the "equalization" decree and complained that he had not been afforded an opportunity to be heard. 239 U.S. at 444 .

If mere numbers were dispositive, it would seem to follow that in class actions the class or even its champion should have no constitutional right to the procedural benefits of an adjudicative hearing. Yet no one suggests such a result. See Supreme Tribe of Ben-Hur v. Cauble, supra.

13 See Scenic Hudson Preservation Conference v. FPC, 354 F.2d 608, 616-17 (2d Cir. 1965), cert. denied, 384 U.S. 941 (1966). 
parking surcharges in order to diminish center-city air pollution, ${ }^{18}$ and Department of Transportation rules requiring auto makers to install devices that disable a car from operating unless safety belts are fastened ${ }^{19}$ - have been withdrawn as a result of adverse political pressure.

But even here there are some grounds for doubt. The relative rarity of clear-cut examples, and the fact that the rules in the two above examples directly affected vast numbers of people, point up the limited availability of political relief. To be sure, the possibility of legislative intervention, presumably often mirroring public sentiment, sometimes operates prophylactically to prevent an agency from adopting socially unacceptable rules. Even preliminary steps towards legislative activity, such as subcommittee hearings, may cast a shadow on agency zeal. But for vast areas of decision making normally classified as legislative rather than adjudicatory, one must retain serious doubts about the efficacy of the political check, particularly in view of the tortuous path of legislation, and the enormous number of rules being promulgated by administrative agencies.

Justice Holmes's distinction may appear in a still more plausible light if the intellectual processes involved in fact-finding for rulemaking purposes are compared with those employed in adjudication..$^{20}$ Both types of decision involve (1) gathering evidence in the form of sense perceptions, and (2) drawing inferences from the perceptions. Consider first an example of adjudication-a simple automobile negligence case-in which the plaintiff claims, through largely circumstantial evidence, that the accident was due to the defendant's drunken driving. Witnesses may testify to their experiences in terms of certain raw perceptions: witness $A$ that he perceived tire marks on the pavement in a certain configuration; witness $B$ that he saw the defendant stagger from a tavern ten minutes before the accident; witness $C$ that he examined the wrecked cars and perceived the nature of the damage to each car; witness $D$ that he examined the plaintiff in the hospital and perceived the injuries to his body. If the fact-finder is to make anything of these perceptions, a second type of evidence will also be neces-

1" See 39 Fed. Reg. 1848 (1974). Ultimately, Congress passed legislation forbidding the EPA to require parking surcharges. See Energy Supply \& Environmental Coordination Act of 1974, Pub. L. No. 93-319, §4(b), 88 Stat. 246 (June 22, 1974).

11 49 C.F.R. $\$ 571.208$ (1973).

${ }^{20}$ As used in this discussion, the term "adjudication" refers only to the application of rules, not to their formulation (even within an adjudicatory proceeding). 
sary. Witnesses will therefore be asked to testify to certain inferences that may be drawn from the perceptions: witness $A$ may give an opinion about the speed and direction of the cars; witness $C$ about the cost of repairs and other appraisable property loss; witness $D$ about the expected medical expenses and disabilities of the plaintiff. The witnesses may allude to a body of established knowledge and perhaps to particular experiments and case histories to substantiate their opinions. The fact-finder will assess the credibility of the perceptions and the probability of the suggested inferences, and then determine what probably happened and how much injury resulted.

Superficially, the process of developing factual support for a proposed rule will run a similar course. In the case of a health regulation, for example, the agency may begin with studies setting forth certain raw perceptions: that a group of initially healthy rats demonstrated symptoms similar to those of cancer after exposure to a certain chemical. The agency must then determine whether to infer a significant risk to humans from the demonstrated risk to rats. Parties may offer studies purporting to show that the disputed chemical has had no carcinogenic effect on dogs or monkeys; that even for rats there is a threshold level of exposure, below which no carcinogenic effect has been perceived; or that no one has ever perceived a carcinogenic effect on humans exposed to the disputed chemical. This process, too, will raise issues concerning the accuracy of the perceptions of raw data and the plausibility of the inferences sought to be drawn. The agency will conclude with some judgment about the range of probability of cancer at various levels of exposure.

At some point, however, the intellectual process will diverge from that involved in adjudication. Because the agency's legislative mandate will almost certainly have been formulated in rather general terms (calling, perhaps, for the imposition of restrictions reasonably intended to promote human health), knowing the level of risk associated with various levels of exposure will not dispose of the issue. Trade-offs based essentially upon value judgments will be necessary. ${ }^{21}$ By contrast, a court or jury finding facts in order to

${ }^{21}$ Suppose, for example, that a completely value-neutral fact-finder would conclude that workers exposed to a given level of the chemical will annually suffer a one-in-ten-thousand risk of contracting cancer; that the only feasible restriction of the industrial process is total prohibition; and that this process is essential for the manufacture of a medically useful drug. At this stage of rulemaking, the agency members inescapably doff their hats as value-neutral fact-finders and assume the role of legislators of values, deciding whether society should accept the cancer risk or do without the drug. 
apply a rule of law is theoretically able to do so in a value-free way. ${ }^{22}$ Authoritative statements of the rule, including where the burden of persuasion lies and how high the standard of proof is, will largely have resolved the value issues.

At this point Justice Holmes's readiness to limit a person adversely affected by administrative rulemaking to his political remedy takes on a slightly different coloration. The Bi-Metallic preference for the political remedy makes sense in comparative terms. Holmes may have meant not that the political remedy is ideal, but merely that when the ultimate issues require value judgments that are not susceptible to "proof," 23 the check afforded by the procedural protections of a hearing may be even less worthwhileespecially when one considers the costs in time and energy involved in such procedural checks.

This is not to say that the procedural requirements associated with adjudication are of no use as a check to lawless rulemaking. Whenever the perception of raw data is at stake, or doubts are raised about the analytical underpinnings of competing inferences, those requirements may play more or less the role that they do when a rule is being applied to a historical episode.$^{24} \mathrm{But}$, since agency rulemak-

The model is complicated by the fact that insertions of values into the rulemaking process do not necessarily come tidily at the end, as I have implied in the text. A scientist's expert judgment about factual probabilities is often clouded by concern about the result-concern that either a "too restrictive" or "too lenient" regulation may emerge unless the agency accepts his view as to the correct factual inference. Here mystical incantations-such as "expert opinion" or "engineering judgment"-are likely to conceal the extent to which the proposed inference is based on value judgment rather than objective analysis of probabilities. Thus, it is perhaps significant that agencies rarely use advanced methods of statistics to express their factual findings in terms of probabilities. But compare the technique employed by the EPA in the emissions suspension case, discussed in text and notes at notes 231-33 infra.

22 Of course, there will be gray areas, where the rule is so ill-defined that a covert value judgment must be made in order to apply it to the fact. $C f$. O. Holmes, The Common Law 123-25 (1881). And judges or juries may inject their values into the fact-finding. For example, in the face of a near-certain probability of contributory negligence, they may decide for the plaintiff because of their value judgment that the risk of mistakenly denying relief to a plaintiff with a good claim is far less acceptable than the risk of mistakenly giving relief to a plaintiff without a claim. Nonetheless, it seems fair to say that values play a far less signifcant role in the finding of facts for the purpose of applying law than for the purpose of promulgating law.

${ }^{23}$ See Grey, Book Review, 25 Stan. L. Rev. 286 (1973); Leff, Book Review, 60 VA. L. Rev. 451 (1974).

2t This is apparently what Professor Robinson meant when he wrote:

. . . [I]t is doubtful that predictive judgment is radically different from determinations of historical fact. In both cases the determination must almost invariably rest on general conclusions that are inferred from particular factual data and an evaluation of the probabilities that may be as appropriate for testimonial proof and cross-examination in the one case as in the other. 
ing involves the exercise of a delegated portion of the legislature's power to make trade-offs between competing values, the relative significance of "accurate" factual investigation is reduced. For to the extent that the agency, simply by recasting its value judgment, may achieve its original result despite being forced to correct its factual errors, the benefits that are supposed to be derived from precision are vitiated. ${ }^{25}$

In addition to the pervasiveness of value judgments, there is another factor that may make society less determined to achieve factual accuracy in rulemaking. It is partly captured in Judge Leventhal's epigram in the Blocked Space ${ }^{28}$ case that with some issues "a month of experience will be worth a year of hearings." Seemingly, this distinction sharply dèlineates between adjudication and rulemaking. A party who loses an adjudication will ordinarily never benefit from anything that happens after the judgment in his case is entered; ${ }^{27}$ the victim of an improper rule may hope that experience will show the agency the error of its ways and bring about correction. "Feedback" is possible in the rulemaking context, not in the application of a rule to a past event.

On closer examination, the distinction is not quite such a bright line. First, it ignores the unfortunate circumstance that ultimate

Robinson, The Making of Administrative Policy: Another Look at Rulemaking and Adjudication and Administrative Procedure Reform, 118 U. PA. L. REv. 485, 522 (1970).

${ }^{25}$ A recent decision of the District of Columbia Circuit, wrestling with the principle that "substantial evidence in the record considered as a whole" shall be the scope of review for regulations promulgated under the Occupational Safety and Health Act, 29 U.S.C. § 655(f) (Supp. 1975), analyzed the rulemaking function in somewhat similar terms. Judge McGowan wrote:

What we are entitled to at all events is a careful identification by the Secretary, when his proposed standards are challenged, of the reasons why he chooses to follow one course rather than another. Where that choice purports to be based on the existence of certain determinable facts, the Secretary must, in form as well as substance, find those facts from evidence in the record. By the same token, when the Secretary is obliged to make policy judgments where no factual certainties exist or where facts alone do not provide the answer, he should so state and go on to identify the considerations he found persuasive.

Industrial Union Dep't, AFL-CIO v. Hodgson, 499 F.2d 467, 475-76 (D.C. Cir. 1974). Judge McGowan's term "policy judgments" seems to encompass what I have refered to as value judgments-principles that cannot be "proven" right or wrong. Where value judgments were involved, therefore, the court concluded that it could only ask the Secretary to identify the considerations he had found persuasive, so that the court might be assured that he had acted in compliance with the statutory purposes. For a somewhat looser formulation of the same distinction, see Amoco Oil Co. v. EPA, 501 F.2d 722, 740-41 (D.C. Cir. 1974).

${ }^{28}$ American Airlines, Inc. v. CAB, 359 F.2d 624, 632-33 (D.C. Cir. 1966), cert. denied, 385 U.S. 843 (1966).

${ }^{n}$ It might seem that injunctive decrees, which are frequently made modifiable by the issuing court, are an exception. But such "regulatory" decrees are actually a good deal like administrative rules. 
correction of the error will not indemnify the interim losers for what they suffered before the agency saw the light. ${ }^{28}$ Second, it may take an extraordinarily dreadful rule to make Judge Leventhal's time estimate realistic. In the Blocked Space case, for example, four years elapsed before the agency abandoned the rule, despite some reason to believe that the bases ultimately asserted for the reversal should have been reasonably apparent to the agency at the time of the original adoption. ${ }^{29}$ Third, the teachings of experience (except in the most egregious cases) are likely to be subject to precisely the same ambiguities as the factual data on which the rule originally was based. If the rule fails to deliver the hoped-for results, its proponents will often be able to explain away its failure and to suggest supplementary rules that may bring about success. The absence of an effectively isolated "control group" may make it practically impossible to build an impregnable factual record against such contentions. Fourth, the establishment of a bureaucracy to implement the rule will create an institutional obstacle to repeal, tending to offset whatever advantages experience may have provided..$^{30}$

It seems, nevertheless, that there is force to Judge Leventhal's point. And although his epigram deals with the peculiar ability of an agency to conduct a legislative experiment (adopting a rule to see how it works out), the analysis can also be applied to the agency's institutional ability to conduct all kinds of experiments, some of which may be scientific or technical, rather than legislative. The role of such experiments in rulemaking suggests several factors that further militate against making rules by using the kind of procedures associated with adjudicative fact-finding.

First, the rulemaking framework offers the possibility of discarding the results of a questionable study and conducting an improved experiment. If, for instance, someone challenges whether

${ }^{25}$ Perhaps the notion that rules produced by "rulemaking" have only "future effect" accounts in part for the general disregard of this fact. See 5 U.S.C. $\$$ 551(4) (1970). Of course, the effects of all human decisions take place in the future, but regrettably these effects still may heavily penalize past decisions. Thus a rule purporting to have only future effect ("fossilfueled electric plants must reduce their emissions of sulfur dioxide to so many grams per BTU equivalent of fuel used in the process") may have a devastating impact on the value of past investments-far more so than a knuckle-rapping fine for a past violation.

2 See Robinson, supra note 24 , at 530-31.

${ }^{30}$ In practice, the most clearcut effect of experience may be to reinforce an agency's successful initial inclination. If, for example, an agency adopts a regulation in the face of a "parade of horribles" predicted by the parties who expect to be adversely affected, and the horribles demonstrably fail to materialize, the agency may rightly be emboldened to similar ventures in the future. The peril, of course, is that the agency may misread, or exaggerate, the lessons of the first success. 
those who conducted a given experiment with rats measured accurately the amounts of a substance to which they were subjected, or if it is suggested that the study is flawed given the potential effects of the hypodermic needle employed, it may be possible to conduct another study that eliminates the alleged defects. Although such experimental flexibility may occasionally be possible in connection with adjudication also, the chances seem much more remote in the latter context.

Second, the sort of error in perception that is the typical target of cross-examination possesses relatively minor significance in the rulemaking framework. Almost any important experiment will involve observing a substantial number of events or conditions-for example, the health of a number of rats after various exposures to an allegedly cancer-producing substance. Although individual errors may well occur, one would expect that, in the absence of a methodological error, they would tend to cancel each other out. Consequently, there is less need for elaborate procedures to verify each observation than when the issue is, say, whether the defendant was speeding.

The Bi-Metallic case itself illustrates the point. Although the case involved "values" of property, one cannot argue that "value judgments" were to be made. In making property tax assessments subjective concepts of "value"-what the owner would demand for his property or any particular person might offer for it-are largely put aside in favor of a (purportedly) objective concept, "market value." Why then should Denver property owners have been denied an opportunity to contest the proposition that their properties had been undervalued by 40 percent?

The concept of experiments gives an answer. Assume that the state board employed a valuation method that would have been regarded as an acceptable analytical method given the standards prevalent at that time. ${ }^{31}$ Presumably, this method involved comparisons between the Denver assessor's valuations and "true" market values. Miscomputations in the valuation of any particular property would tend to be of minimal significance for a large sampling; in the absence of systematic error, miscomputations in one direction would presumably tend to be offset by error in the opposite direction. Thus, the acceptability of the state board's judgment would turn upon the propriety of its method; if its method was improper,

${ }^{31}$ Neither the Supreme Court opinion nor that of the Supreme Court of Colorado offers a clue as to the method employed. State Bd. of Equalization v. Bi-Metallic Inv. Co., 56 Colo. 512, 138 P. 1010 (1914), aff'd, 239 U.S. 441 (1915). 
its judgment would be invalid as arbitrary or capricious, at least at some point. The Court may have felt that judicial review for arbitrariness (together with political remedies) represented sufficient protection against sloppy agency fact-finding. ${ }^{32}$

This is not the place to attempt a comprehensive analysis of the line between rulemaking and adjudication for purposes of determining when the constitutional requirement of due process calls for a "hearing." But, as will be seen, the factors that have just been outlined may help to explain why the hybrid rulemaking procedures mandated by the courts have, in the end, provided very little tangible benefit to the aggrieved parties.

\section{SOURCes of Judicial Power to IMPose Hybrid Rulemaking Procedures}

The courts' occasional insistence that agencies observe procedural niceties not prescribed in section 553 inevitably poses a question of legitimacy. Whether the potential objection be framed in terms of "separation of powers," "jurisdiction," or whatever, it is not self-evident that the federal judiciary has any basis for giving independent regulatory agencies or branches of the executive department instructions about how they should engage in factgathering.

\section{A. Section 553}

We should note preliminarily that the courts have by no means explored the full reach of section 553's requirements. For example, section 553(c) requires the agency to give interested persons "an opportunity to participate in the rule making through submission of written data, views, or arguments with or without opportunity for oral presentation." That provision appears to give an agency discretion to grant or withhold the chance for oral presentation; but since section 706(2)(A) authorizes a court to set aside agency action found to be "an abuse of discretion," denial of a request for oral argument

32 Yet one may question whether judicial review for arbitrariness represented a feasible avenue for relief at the time of $B i$-Metallic. It is very hard to see how the complainants in that case could have exposed any methodological error to judicial view. The requirement that agencies must make formal findings did not appear until 1922. See Wichita R.R. \& Light Co. v. Public Util. Comm'n, 260 U.S. 48, 58 (1922). Furthermore, the complainants probably could not have made a colorable allegation that the ruling was confiscatory and thereby obtained a trial, $c f$. Chicago, M. \& S.P. Ry. v. Tompkins, 176 U.S. 167 (1900), and outside the area of confiscation, apparently, judicial trial of legislative facts was still unavailable. See Borden's Farm Prods. Co. v. Baldwin, 293 U.S. 194, 211-13 (1934), and cases cited. 
could, in some cases, be held reversible error. ${ }^{33}$

Section 553(c)'s requirement of an opportunity to participate could also give rise to claims that the "notice" required by section 553 (b) should be broadly conceived. Although section 553(b)(3) merely requires that the notice include "either the terms or substance of the proposed rule or a description of the subjects and issues involved," an objector could argue that in some circumstances the 553 (b) (3) notice should set forth not only the proposed regulation but also a statement of its factual premises and methodology, sufficiently detailed to permit objectors to make a meaningful use of their section 553(c) "opportunity to participate."

\section{B. The Constitution}

The APA definition of a rule, "an agency statement of general or particular applicability and future effect designed to implement, interpret, or prescribe law or policy . . . .,"35 is so broad that it obviously must cover a number of circumstances that require adjudicatory procedures because of the due process clause. A literal reading of the APA might suggest that Congress has prescribed only "notice-and-comment" rulemaking for at least some of these situations. The Supreme Court's decision in Wong Yang Sung $v$. $M c$ rrath $^{36}$ indicates, however, that the APA itself automatically sweeps such cases into the class governed by the adjudicatory techniques of sections 556 and 557. In Wong Yang Sung, the Court dealt with section 554's "separation-of-functions" rule, which prohibits agency personnel involved in investigatory or prosecutorial functions from also participating in agency decision-making. By its terms, this provision applies to "every case of adjudication required by statute to be determined on the record after opportunity for an agency hearing," ${ }^{37}$ and the Court held that the prohibition also applies to an adjudication required by the Constitution-but not by

${ }^{33}$ See Chemical Leaman Tank Lines, Inc. v. United States, 368 F. Supp. 925, 946 (D. Del. 1973) (noting that the denial of an opportunity to make an oral presentation is "presumably" reviewable for abuse of discretion, but finding no abuse in the circumstances presented). It might be argued, however, that such reliance on section 706(2)(A)'s authorization of reversal for abuse of discretion would be an unwarranted extension of section 706(2)(D), which authorizes the reviewing court to overturn agency action for failure to observe "procedure required by law."

31 Judge Leventhal relied in part on this argument in Portland Cement Ass'n v. Ruckelshaus, 486 F.2d 375, 393 n.67 (D.C. Cir. 1973).

${ }^{35} 5$ U.S.C. $\S 551(4)(1970)$. But see id. \& 551(6), which excludes licensing from the category of rulemaking.

${ }^{36} 339$ U.S. 33 (1950).

375 U.S.C. $\S 554(a)$ (1970) (emphasis added). 
statute-to be determined in that way.

Section 553(c) employs almost identical language: "[w]hen rules [as defined in the language quoted above] are required by statute to be made on the record after opportunity for an agency hearing, sections 556 and 557 of this title apply instead of this subsection." And the remedial purpose of the APA, invoked in Wong Yang Sung to justify a generous interpretation of section 554, would seem equally pertinent in the construction of section 553(c) ${ }^{38}$ In most situations, therefore, when the Constitution requires something more than section 553 procedures, it will require the full gamut of procedures mandated for "on-the-record" rulemaking. On the other hand, to the extent that rules of general (as opposed to particular) applicability are concerned, the burden of Bi-Metallic would seem to be that the Constitution imposes no procedural constraints upon the agency-other than the restraints, if any, it might impose upon a legislature acting directly. ${ }^{39}$

\section{The Agency's Authorizing Statute}

Congress is of course free to require that an agency, in promulgating regulations, adhere to procedures superseding those of section 553, and in recent years it has often done so. These requirements have included consultation with a specific person or group, creation of and consultation with an advisory committee, and provision of an opportunity for oral testimony and argument..$^{40}$ Frequently, the Congressional message is far from clear, ${ }^{41}$ thus leaving substantial room for judicial interpretation.

It is fair to say that the attitude of the Supreme Court toward these ambiguities has altered sharply since such decisions as Morgan $I^{42}$ and Morgan $I I .{ }^{43}$ Both addressed the question of how a statutory "full hearing" obligation affected the Secretary of Agriculture's power to set "just and reasonable" rates for stockyards. Morgan I found the phrase to contain the now much-diluted requirement that the one who decides the case must hear, ${ }^{44}$ and Morgan II

3* See Note, The Judicial Role in Defining Procedural Requirements for Agency Rulemaking, 87 HaRv. L. REv. 782, 791 (1974) [hereinafter cited as HaRvard NotE].

* Bi-Metallic Inv. Co. v. State Bd. of Equalization, 239 U.S. 441, 445 (1915). But cf. Appalachian Power Co. v. EPA, 477 F.2d 495, 503 (4th Cir. 1973).

" See Hamilton, Procedures for the Adoption of Rules of General Applicability: The Need for Procedural Innovation in Administrative Rulemaking, 60 CALIF. L. REv. 1276, 131318 (1972).

4Id. at 1319-23.

12 Morgan v. United States, 298 U.S. 468 (1936).

13 Morgan v. United States, 304 U.S. 1 (1938).

" 298 U.S. at 481. 
found it to encompass a requirement that the issues be formulated in advance of final decision with sufficient clarity that opponents of the proposed outcome could know what they had to oppose. In both opinions, Chief Justice Hughes characterized the proceedings as "quasi-judicial."45 From the tenor of the opinions, one might suspect that the Court would have found that the statutory phrase "full hearing" embodied, in some degree, almost every conceivable attribute of adjudicatory proceedings.

The most recent Supreme Court interpretation of a Congressional "hearing" requirement is worlds apart. United States $v$. Florida East Coast Railway Co. ${ }^{46}$ paralleled the Morgan cases in that it involved the power of an agency (here the ICC) to prescribe rates for the future. The Interstate Commerce Act ${ }^{47}$ provided that the rate prescription should be made only "after hearing." Speaking through Justice Rehnquist, the Court held that the "hearing" requirement did not trip the case over into the section 556-557 class, ${ }^{48}$ and, further, that the requirement was fully satisfied by a section 553 proceeding. ${ }^{49}$ The ICC proceeding was undoubtedly "rulemaking" as defined in the APA, so that section 553 would have governed if the Interstate Commerce Act had been silent about procedures; consequently, the Court's decision rendered the latter statute's express requirement of a "hearing" completely without practical effect.

The Court's handling of an argument based upon ICC $v$. Louisville \& Nashville Railroad Co. ${ }^{50}$ superficially suggests that in other contexts a statutory requirement of a "hearing" can be read to call for more than section 553 procedures. Louisville \& Nashville had interpreted a similar provision to require that all "parties must be fully apprised of the evidence submitted or to be considered, and must be given opportunity to cross-examine witnesses, to inspect documents and to offer evidence in explanation or rebuttal." the statute originally authorizing the Florida East Coast ratemaking proceeding had been enacted just four years after Louisville \&

${ }^{45} 298$ U.S. at 480 ; 304 U.S. at 14, 18.

46 U.S. 224 (1973).

" Section 1(14)(a) of the Interstate Commerce Act, as amended, provides:

The Commission may, after hearing on a complaint or upon its own initiative without complaint, establish reasonable rules, regulations, and practices with respect to car service by common carriers by railroad subject to this chapter, including the compensation to be paid . . . .

49 U.S.C. § 1(14)(a) (1970).

43410 U.S. at $234-38$.

a Id. at $238-46$.

so 227 U.S. 88 (1913).

s1 Id. at 93. 
Nashville, the railroads in Florida East Coast argued that the phrase should be given the same meaning as in Louisville \& Nashville. Justice Rehnquist rejected the argument, seemingly on the grounds that Louisville \& Nashville involved refunds, while the rates to be fixed in Florida East Coast were prospective only. ${ }^{52}$ The implication would appear to be that the meaning of the statutory term "hearing" may vary according to the nature of the decision to be made.

But this contention fails to consider a significant element of the factual situation before the Court. A ratemaking proceeding involving a refund order would not fall within the terms of section 553 at all, since rules within the meaning of the APA are limited to decisions of "future effect." ${ }^{3}$ Thus, all we are left with is the rather tautological proposition that where an authorizing statute requires a "hearing" in a context to which section 553 is not applicable, the scope of the "hearing" is not confined to the procedures described in section 553.

It might also be argued that Florida East Coast's refusal to give the word "hearing" any meaning at all is limited to statutes antedating the APA..$^{54}$ The argument would be that Congress's use of the term "hearing" in 1917 can be attributed merely to the then existing vacuum in common understanding about the normal procedures for rulemaking-a vacuum filled by enactment of the APA. The corollary would be that a "hearing" requirement in a post-APA statute has to be given some meaning, namely, that it requires procedures beyond those coming into effect automatically under section 553 .

The difficulty with the argument is that the Court in Florida East Coast went to some lengths to chill any such notion. The Interstate Commerce Act had been amended in 1966 to direct the ICC to consider the impact of the rates upon the adequacy of the nation's freight car supply..$^{55}$ Because this legislative action had simply altered the substantive terms under which the ICC was to exercise its preexisting authority, the Court could have disregarded the amendment and addressed its decision only to "hearing" requirements enacted prior to the passage of the APA. Instead, Justice Rehnquist wrote: "Under these circumstances, confronted with a grant of substantive authority made after the Administrative Procedure Act was enacted, we think that reference to that Act, in which Congress

\footnotetext{
32410 U.S. at 244-45.

ss 5 U.S.C. § 551(4) (1970).

st Cf. HaRvard Note, supra note 38 , at 794.

ss See 410 U.S. at $225-31$.
} 
devoted itself exclusively to questions such as the nature and scope of hearings, is a satisfactory basis for determining what is meant by the term 'hearing' used in another statute." 56 Thus the Court aggressively insisted upon treating the ICC's authorizing statute as bearing not only a 1917 date but also a 1966 one. ${ }^{57}$

In sum, where Congress has required a "hearing" in a case that would otherwise be covered by section 553 , it will be difficult to persuade a court after Florida East Coast that the "hearing" requirement calls for additional adjudicative-type procedures. Constitutional overtones or exceptionally clear statutory history might prove persuasive, but in run-of-the-mill cases the Supreme Court will likely declare that a "hearing" requirement is fully met by compliance with section 553 .

A similar ambiguity is presented in statutory provisions for judicial review that establish a standard of "substantial evidence" and call for an agency to file with the court "the record upon which the order complained of was entered."58 The Attorney General's manual on the APA viewed such provisions as making sections 556 and 557 applicable ${ }^{59}$ and two panels of the District of Columbia Circuit have found in them a basis for requiring hybrid rulemaking in two of the cases examined in this article, Mobil Oil Corp. v. FPC $C^{80}$ and Public Service Commission v. FPC. ${ }^{11}$ On the other hand, the Tenth Circuit in Phillips Petroleum Co. v. FPC, ${ }^{82}$ and another panel

${ }^{36}$ Id. at 240 (emphasis added).

${ }^{57}$ Alternatively, the argument could be inverted. Working from the sentence quoted in the text, one could contend that Florida East Coast's narrow reading of the "hearing" requirement should be confined to statutes enacted or reenacted after the adoption of the APA. See Comment, Ratemaking by Informal Rulemaking Under the Natural Gas Act, 74 Colum. L. REv. 752, 759-60 (1974). But the Supreme Court's decision in United States v. AlleghenyLudlum Steel Corp., 406 U.S. 742 (1972), and the references to that case in Florida East Coast substantially undermine the claim. In Allegheny-Ludlum, the Court reviewed a rule promulgated by the ICC under the same Interstate Commerce Act provision in its unamended form. The Court summarily classified the proceeding as coming under section 553. See 406 U.S. at 755-58. In Florida East Coast, Justice Rehnquist reaffirmed that holding and framed the issue before him as a question of whether the 1966 amendment justified any different result. 410 U.S. at 234-35.

ss See Natural Gas Act § 19, 15 U.S.C. § 717r(b) (1970).

39 United States Department of Justice, Attorney General's Manual of the Administrative Procedure Act 33 (1947) [hereinafter cited as Attorney General's Manuat]. This passage is essentially an interpretation of the proviso of section 553(c), which makes sections 556 and 557 applicable when "rules are required by statute to be made on the record after opportunity for an agency hearing."

${ }^{80} 483$ F.2d 1238, 1257-63 (D.C. Cir. 1973).

4147 F.2d 1043, 1069-71 (D.C. Cir. 1973), vacated and remanded, 417 U.S. 964 (1974).

${ }^{62} 475$ F.2d 842, 851-52 (10th Cir. 1973), cert. denied, 414 U.S. 1146 (1974) (despite the fact that the ratemaking in question evidently involved retroactive application, so that all 
of the District of Columbia Circuit in American Public Gas Association v. FPC, ${ }^{63}$ have seemingly rejected such contentions. The issue has been the subject of considerable scholarly comment; ${ }^{64}$ and the Administrative Conference has expressly recommended against finding that a statutory requirement of "substantial evidence on the record" implies any sort of procedural obligation. ${ }^{55}$ Florida East Coast suggests, of course, that the Supreme Court will not read ambiguous language of this kind very expansively.

\section{The Necessities of Judicial Review}

As the above discussion demonstrates, and as the cases have tacitly recognized, the Constitution and specific statutory provisions often provide no firm foundation for the imposition of hybrid rulemaking requirements. But the courts have not been deterred by legislative silence. Declining to insist on direct statutory support, they have adopted a pragmatic outlook, resting their holdings on the necessities of substantive review.

The typical situation prompting this stance can be briefly sketched. No matter what the standard of review in an appeal from an agency rulemaking proceeding, the record before the court (including detailed factual allegations by the challengers) may leave room for doubt about a necessary factual predicate of an otherwise valid rule, so that the court is unable, without more, to affirm the rule. Take, for example, the primary ambient air standards that the Environmental Protection Agency is authorized to prescribe in order to "protect the public health." ${ }^{66}$ A complete absence of any link between public health and the standard promulgated for any given pollutant will presumably be fatal to the validity of that standard. If the record compiled by the agency contains only vague and conclusory statements about the alleged link, and if a challenger offers precise factual contentions rebutting the existence of the link, the

APA rulemaking provisions were inapplicable to that extent, see id. at 857 (Seth, J., dissenting)).

as 498 F.2d 718 (D.C. Cir. 1974).

"Verkuil, Judicial Review of Informal Rulemaking, 60 VA. L. REv. 185, 247-48 (1974); Scalia \& Goodman, Procedural Aspects of the Consumer Product Safety Act, 20 U.C.L.A.L. Rev. 899, 934-35 (1973); HaRvard Note, supra note 38, at 803-05.

A contention has also been advanced that a provision for judicial review of the "record," without more, triggers section 553(c)'s proviso and renders sections 556 and 557 applicable. The position has been rejected in Automotive Parts \& Accessories Ass'n v. Boyd, 407 F.2d 330, 336-37 (D.C. Cir. 1968); cf. Hamilton, supra note 40, at 1322-23.

os See Recommendation 74-4, 1973-74 REPORT of the AdMinistrative ConfERENCE of the UNited STATES 58.

6 Clean Air Act $\S 109,42$ U.S.C. $\S 1857 \mathrm{c}-4(\mathrm{~b})(1)$ (1970). 
court cannot approve the standard until factual clarification is achieved.

There are three devices for supplementing the record. The first is the main subject of this article: a remand for hybrid rulemaking. The other two are (1) trial de novo in court, ${ }^{67}$ and (2) a remand to the agency after the manner of Chenery $I,{ }^{88}$ that is, with a demand for a more precise articulation of the findings and considerations upon which the rule is based, or for a demonstration that the rule is founded on factors made relevant by the authorizing statute.

The two alternative devices require serious consideration. The option of judicial trial de novo puts the issue of hybrid rulemaking into perspective: if a court may indeed employ judicial trial, then it would appear to have, almost a fortiori, a power to remand to the agency with specific procedural instructions. The option of remand for a better statement of reasons also contributes perspective, but from a different angle: to the extent that it can assure a record sufficient for substantive judicial review, its availability militates against judicial use of the more onerous device of remanding with procedural requirements. Thus, before undertaking our discussion of whether the pragmatic justification for ordering hybrid rulemaking is well founded in reality, it is necessary to seek to define the circumstances under which the other devices serving the same goal may be more appropriate.

1. Trial De Novo in Court. The APA evidences a Congressional assumption that judicial trial de novo will be appropriate in some circumstances, but it does not state what those circumstances may be. Section 706(2) provides that the reviewing court shall "hold unlawful and set aside agency action, findings, and conclusions found to be ... (F) unwarranted by the facts to the extent that the facts are subject to trial de novo by the reviewing court."

Two recent Supreme Court opinions have given section $706(2)(F)$ a rather narrow reading - a reading largely at odds with the statutory history. In Citizens to Preserve Overton Park, Inc., $v$. Volpe, ${ }^{69}$ the petitioners challenged a decision by the Secretary of Transportation that there was "no feasible and prudent alternative" to the use of some Memphis parkland for highway construction. ${ }^{70}$

${ }^{67}$ See text and notes at notes 215-17 infra for a discussion of the problem of finding a basis for district court jurisdiction for this purpose.

${ }^{83}$ SEC v. Chenery Corp., 318 U.S. 80, 93-94 (1943).

${ }^{89} 401$ U.S. 402 (1971).

${ }^{70}$ That finding was a prerequisite to the use of federal funds for the highway. Transportation Act of $1966 \S 4(f), 49$ U.S.C. § 1653(f) (1970); Federal-Aid Highway Act of $1968 \S 18(\mathrm{a})$, 23 U.S.C. $\$ 138(1970)$ : 
The Court expressly rejected the plaintiffs' claim of a right to trial de novo:

Petitioners' alternative argument also fails. De novo review of whether the Secretary's decision was "unwarranted by the facts" is authorized by $\S 706(2)(F)$ in only two circumstances. First, such de novo review is authorized when the action is adjudicatory in nature and the agency factfinding procedures are inadequate. And, there may be independent judicial factfinding when issues that were not before the agency are raised in a proceeding to enforce nonadjudicatory agency action. H.R. Rep. No. 1980, 79th Cong., 2d Sess. Neither situation exists here. ${ }^{71}$

The Court instead ordered a remand to the district court "for plenary review of the Secretary's decision," a review that might "require the administrative officials who participated in the decision to give testimony explaining their action."72 Camp v. Pitts ${ }^{13}$ took a similar view of section 706(2)(F). An applicant for a charter authorizing a new bank ${ }^{74}$ challenged the Comptroller of the Currency's denial of the application. The Court held that the district court's holding of trial de novo on the merits was error, and ordered the case remanded for an inquiry of the type prescribed by Overton Park. ${ }^{75}$

The Overton Park Court's citation to the House Judiciary Committee report on the APA is curious. The report had summarized the meaning of section $706(2)(\mathrm{F})$ in this way:

In short, where a rule or order is not required by statute to be made after opportunity for agency hearing and to be reviewed solely upon the record thereof, the facts pertinent to any relevant question of law must be tried and determined de novo by the reviewing court respecting either the validity or application of such rule or order-because facts necessary to the determination of any relevant question of law must be determined of record somewhere and, if Congress has not provided that an agency shall do so, then the record must be made in court. ${ }^{76}$

1401 U.S. at 415.

72 Id. at 420.

73 U.S. 138 (1973).

7 See 12 U.S.C. $\$ 27$ (1970).

75 411 U.S. at 141-43.

3t The remainder of the paragraph dealing with section 706(2)(F) was as follows:

The sixth category, respecting the establishment of facts upon trial de novo, would require the reviewing court to determine the facts in any case of adjudication not subject to sections 7 and 8 or otherwise required to be reviewed exclusively on the record of a 
The Committee thus apparently assumed that judicial trial de novo might be an appropriate device when the substantive validity of an agency rule turned upon the resolution of some factual claim. ${ }^{77}$

The Overton Park Court appears to have taken one of the Committee's illustrations and used it to illustrate a completely different rule. The Committee had said: "Where a court enforces or applies an administrative rule, the party to whom it is applied may for example offer evidence and show the facts upon which he bases a contention that he is not subject to the terms of the rule." ${ }^{\prime 78} \mathrm{Be}$ cause such cases normally involve facts unique to the subject of the enforcement proceeding, they do appear to fit within the Court's second category-instances "when issues that were not before the agency are raised in a proceeding to enforce nonadjudicatory agency action." 39 But the passage as a whole rebuts any notion that the

statutory agency hearing. It would also require the judicial determination of facts in connection with rulemaking or any other conceivable form of agency action to the extent that the facts were relevant to any pertinent issues of law presented. For example, statutes providing for "reparation orders," in which agencies determine damages and award money judgments, usually state that the money orders issued are merely prima facie evidence in the courts and the parties subject to them are permitted to introduce evidence in the court in which the enforcement action is pending. In other cases, the test is whether there has been a statutory administrative hearing of the facts which is adequate and exclusive for purposes of review. Thus, adjudications such as tax assessments not made upon a statutory administrative hearing and record may involve a trial of the facts in The Tax Court or the United States district courts. Where administrative agencies deny parties money to which they are entitled by statute or rule, the claimants may sue as for any other claim and in so doing try out the facts in the Court of Claims or United States district courts as the case may be. Where a court enforces or applies an administrative rule, the party to whom it is applied may for example offer evidence and show the facts upon which he bases a contention that he is not subject to the terms of the rule. Where for example an affected party claims in a judicial proceeding that a rule issued without an administrative hearing (and not required to be issued after such hearing) is invalid for some relevant reason of law, he may show the facts upon which he predicates such invalidity. In short, . . . [etc.]

Senate Committee on the Judiciary, Administrative Procedure Act Legislative History, 79th Cong., 2d Sess. 279 (1946) [hereinafter cited as Legislative History], quoting H.R. ReP. No. 1980, 79th Cong., 2d Sess. (1946). The paragraph alludes to the "sixth category" because it was APA section 10(e)(6) that became 5 U.S.C. $\$ 706(2)(\mathrm{F})(1970)$.

77 The Committee evidently assumed that the occasion for trial de novo would be an enforcement proceeding. But to the extent that modern concepts of ripeness have accelerated judicial determination of a rule's validity, one would expect that the trial contemplated by the Committee would frequently be accelerated also. See also text and notes at notes 218-19 infra.

Note that in the Committee's reference to "a rule issued without an administrative hearing," the word "hearing" must mean something more than a proceeding under section 553 , for the simple reason that under the APA there is practically no rule that can be issued at all without at least a section 553 proceeding. See 5 U.S.C. $\$ 553$ (a) (1970).

${ }^{78}$ Legislative History 280.

79401 U.S. at 415. 
example was intended to delimit the scope of trial de novo outside the adjudicatory context. The Senate Judiciary Committee report, with a few differences in wording, is similarly broad. ${ }^{80}$

Earlier statutory history of the APA mentions a concrete example of how trial de novo can supply the factual predicate of rules promulgated without a hearing. The Attorney General's Committee on Administrative Procedure, appointed in 1939 to inquire into existing administrative practices and procedures, alluded in its final report ${ }^{81}$ to Houston v. St. Louis Independent Packing Co. ${ }^{82}$ a Supreme Court case involving sausage-labeling rules of the Secretary of Agriculture. Congress had authorized the Secretary to issue rules implementing the statutory prohibition of interstate sale of meat under "any false or deceptive name." The Secretary thereupon banned the interstate sale of sausage containing more than two percent cereal, and a sausage manufacturer filed a bill in equity to challenge the decision. The district court held "an elaborate trial" to investigate the typical contents of "sausage" and the public's knowledge about the true contents of so-called "sausage." upheld this procedure, the Supreme Court seems to have accepted, at least by implication, the principle of holding such a trial de novo in review of nonrecord rulemaking. ${ }^{84}$

De novo review of this sort is, of course, entirely different from the theories of "jurisdictional fact" Under those doctrines, the Court has ordered judicial trial de novo, or at least a very broad scope of judicial review, over certain special

80 Legislative History 214, quoting S. ReP. No. 572, 79th Cong., 1st Sess. (1945).

The Attorney General's Manual argued for a narrow interpretation of section 10(e)(6), but did so only in the context of review of agency adjudications, as opposed to instances where a party draws in question the validity of a rule promulgated under section 553. ATTORNEY General's MaNual 109-10.

si Attorney General's Committee on Administrative Procedure, Administrative Procedure in Government Agencies, S. Doc. No. 8, 77th Cong., 1st Sess. 116 (1941).

×2 249 U.S. 479 (1919).

${ }^{83}$ Id. at $484-85$.

st When judicial review is to take place in the court of appeals rather than the district court, trial de novo is still possible. Sometimes, the court of appeals is authorized to transfer the case to the district court under the Administrative Orders Review Act, 28 U.S.C. $\S 2347$ (1970). Moreover, although it is inconvenient, the court of appeals has the capacity to receive oral testimony, see, e.g., NLRB v. Lambert, 250 F.2d 801 (5th Cir. 1958), or to refer the matter to a master, see, e.g., NLRB v. Little Rock Furniture Mfg. Co., 123 F.2d 868 (8th Cir. 1941); NLRB v. Giannasca, 119 F.2d 756 (2d Cir. 1941). See generally Currie \& Goodman, Judicial Review of Federal Administrative Action: Quest for the Optimum Forum, 75 Colum. L. Rev. 1 (1975).

*s See Crowell v. Benson, 285 U.S. 22 (1932); Ng Fung Ho v. White, 259 U.S. 276 (1922).

ss See St. Joseph Stock Yards Co. v. United States, 298 U.S. 38 (1936); Ohio Valley Water Co. v. Ben Avon Borough, 253 U.S. 287 (1920). 
issues-notwithstanding that those issues have already been resolved by the relevant agencies in adjudicatory hearings whose procedural validity the Court assumed. The theory of the House and Senate Judiciary committees differs in at least two crucial respects. First, by hypothesis the procedure they envisioned is limited to cases where the objecting party has not had an opportunity to build a trial-type record in support of his factual contentions. Second, the procedure is consistent with a narrow standard of review. Thus, assuming that "arbitrary or capricious" defines the scope of review of our hypothetical primary ambient air standard, ${ }^{87}$ and that the EPA must therefore show only a fairly tenuous link between the disputed pollutant and the public's health, the House and Senate committees' view would support judicial trial de novo to ascertain whether even that tenuous link exists.

Despite the apparent rarity of judicial trial de novo in these circumstances, its propriety is demonstrated by the existence of an analogous practice: judicial trial of facts that are necessary to determine the constitutional validity of statutes. Recently, for example, in Cleveland Board of Education v. LaFleur, ${ }^{88}$ the Supreme Court upset school rules requiring pregnant teachers to quit in the fourth or fifth month of pregnancy. In doing so, the Court relied on evidence developed at trial below that there were "large numbers of teachers who are fully capable of continuing work for longer" than the school rules permitted.$^{89}$ On several other occasions, the Court has remanded a case to the trial court to develop a factual record sufficient for a decision on constitutional validity. In Borden's Farm Products Co. v. Baldwin, ${ }^{90}$ for instance, a milk dealer challenged, on due process and equal protection grounds, a statute requiring a state milk control board, in its setting of minimum milk prices, to allow dealers without a "well-advertised trade name" a one-cent downward leeway. The Court remanded for trial to determine whether, as the state contended, the statute preserved preexisting competitive relationships. ${ }^{91}$

It seems that a device that can be employed (where necessary) to verify the factual underpinnings of legislation is equally appropriate for a court that wants to verify the factual support of agency

${ }^{87}$ See 5 U.S.C. $\$ 706(2)(A)(1970)$.

${ }^{88} 414$ U.S. 632 (1974). See generally Karst, Legislative Facts in Constitutional Litigation, 1960 SUP. CT. REv. 75.

814 U.S. at 646.

so 293 U.S. 194 (1934).

'Id. at 207-13. See also cases cited in id. at 211-13; Note, The Presentation of Facts Underlying the Constitutionality of Statutes, 49 HARv. L. REv. 631 (1936). 
rules, when the agency's factual record comes from the so-called "legislative" hearing under section 553. Neither "separation of powers" nor any other doctrine provides a distinction that would make "statutory facts"-facts needed to ascertain whether an agency's regulation is within its statutory power-any more immune to judicial resolution than facts necessary to ascertain whether a statute is within the legislature's constitutional power. ${ }^{92}$

Do the Supreme Court opinions in Overton Park and Camp represent authoritative rejections of this viewpoint? Although the above-cited dicta certainly invite that conclusion, the holdings can clearly be reconciled with the view of the two Judiciary Committees. The mere existence of a state of facts that would support an administrative order is not a sufficient basis for upholding the order if there is no reason to believe the agency relied on those facts. As Justice Frankfurter observed in Chenery I:

Judged, therefore, as a determination based upon judgemade rules of equity, the Commission's order cannot be upheld. Its action must be measured by what the Commission did, not by what it might have done. It is not for us to determine independently what is "detrimental to the public interest or the interest of investors or consumers" or "fair or equitable" within the meaning of $\S \S 7$ and 11 of the Public Utility Holding Company Act of 1935. The Commission's action cannot be upheld merely because findings might have been made and considerations disclosed which would justify its order as an appropriate safeguard for the interests protected by the Act. There must be such a responsible finding. . . . There is no such finding here..$^{33}$

In contexts such as Overton Park and Camp, therefore, where the Court has decided that the agency is not bound to state findings of fact and reasons, it may make sense to direct the lower courts to inquire first into the mental process of the administrator, since only factual support discovered there would sustain his action. Once it has been determined what his factual premises were, however, it should still be open to objecting parties to show, in a proper case,

32 Cf. A Quaker Action Group v. Morton, 460 F.2d 854 (D.C. Cir. 1971), where the court of appeals remanded for a trial to determine whether, as against a first amendment challenge, certain Department of Interior regulations restricting the use of Lafayette Park in Washington, D.C., could be justified as essential to the protection of the President.

33 SEC v. Chenery Corp., 318 U.S. 80, 93-94 (1943). But see Colorado Interstate Gas Co. v. FPC, 324 U.S. 581 (1945). See also SEC v. Chenery Corp., 332 U.S. 194, 196 (1947); Burlington Truck Lines, Inc. v. United States, 371 U.S. 156, 168-69 (1962). 
that those premises are without adequate basis in reality. At this later stage, trial de novo as contemplated by the House and Senate Judiciary committees would seem to be one of the reviewing court's options.

But it may also be asked whether a remand to the agency instead of to a court (in other words, hybrid rulemaking) should be preferred. The most pervasive principle of administrative law-the court's duty to preserve agency autonomy to the maximum extent consistent with performing the functions of judicial review ${ }^{94}$-seems to call for an affirmative answer. The agency's expertise in the relevant substantive area obviously suggests the desirability of that course (although this factor may at times be offset by the agency's lack of experience in holding trial-type hearings).$^{95}$ Moreover, in the normal case it will be the agency's duty to take whatever factual conclusions emerge from testimony under cross-examination, pull them together with any other adequately supported factual findings, and transform them into a rule within the guidelines of its statutory mandate. For the court to take over a segment of the factfinding would truncate the decision-making process. ${ }^{86}$

In sum, the power to conduct substantive review seems to carry with it an implied power to conduct a judicial trial de novo-and, a fortiori, a power to remand to the agency with instructions to conduct a hearing whose procedures will be adequate to assure the necessary airing of the underlying factual claims. Indeed, the de novo trial power should be sparingly exercised, because of the agency autonomy principle.

2. Remand for Clarification. The availability of this device is, particularly since Chenery $I$, unquestioned. The problem is whether it will afford any benefit to the challenging party. If the agency is in a position to accept the challenger's view of the facts, yet arrive at its original conclusion by articulating a new value judgment that was always within its power, a remand of this sort may moot the factual controversy. Alternatively, a remand requiring the agency to respond to detailed factual criticism may lead it to produce reports of experiments and tests that reduce to relative insignificance the critic's attacks on the perceptions relied on in the original proceed-

94 Cf. L. Jaffe, Judicial Control of Administrative Action 425 (1965) (discussing exhaustion).

${ }^{95}$ Note the House Judiciary Committee's unexplained assumption (see text at note 76 supra) that no agency forum would be available for formal fact-finding.

is See NBC v. United States, 319 U.S. 190, 227 (1943); Myers v. Bethlehem Shipbuilding Corp., 303 U.S. 41 (1938); L. JAFFE, supra note 94, at 425. 
ing. ${ }^{97}$ On the other hand, in some instances, such a remand may bring the factual dispute into sharper focus, but not resolve it. Then the court will still be unable to fulfill its duty of substantive review of the rule itself.

In conclusion, courts have several devices at hand for occasions when unresolved factual issues make it impossible for them to review the substance of any agency rule. The judicial trial de novo and the remand for clarification both have roles to play. But courts will sometimes find the former too intrusive and the latter too lax, and will have to consider whether hybrid rulemaking can effectively serve their needs. A look at the cases and their history on remand will provide the background for an empirical discussion of that problem.

\section{The Hybrid Rulemaking Cases: A Review of Developments}

In this section, our study of the cases begins with a survey of how each defendant agency has responded to the decisions, both in the particular disputes occasioning the remand and in the agency's general methods of operation. The next sections use that data to draw inferences about the efficacy of the judicially imposed procedures, namely, (a) the qualified right of cross-examination, and (b) the right to an adequate opportunity to comprehend-and thus to reply to-the data and reasoning relied upon by the agency. Consequently, this section discusses the cases agency-by-agency, and the next sections address them procedure-by-procedure.

\section{A. Department of Agriculture}

The impact of Walter Holm \& Co. v. Hardin ${ }^{98}$ on the Department of Agriculture can fairly be described as modest. The Department's stance is based on a restrictive interpretation of the way that the case relates to the distinctive procedures of commodity marketing regulation; implicitly, perhaps, it is also based on a conclusion that the teachings of the case are of little general use to the Department.

The regulatory context is as follows: section 8c of the Agricultural Marketing Agreement Act of 193799 (the "Marketing Act") authorizes the Secretary of Agriculture to issue marketing orders governing the sale of specified commodities in order to maintain the

${ }^{97}$ Cf. note 192 infra.

\$* 449 F.2d 1009 (D.C. Cir. 1971).

"7 U.S.C. $\$ 608 \mathrm{c}$ (1970), as amended, 7 U.S.C.A. § 608c (Supp. 1974). 
prices received by farmers. The statute requires "due notice of an opportunity for a hearing" 100 as a condition of each order and any amendments to such orders. ${ }^{101}$ The Department has implemented the statute's hearing requirement by issuing regulations providing for procedures that closely resemble a full adversary hearing, ${ }^{102}$ including a right to cross-examination. ${ }^{103}$

Pursuant to these procedures, the Secretary promulgated a marketing order for tomatoes grown in Florida (the "Tomato Marketing Order"). ${ }^{104}$ The order itself provided that the Secretary should issue so-called "regulations" to implement the order, ${ }^{105}$ but it did not prescribe hearings for that purpose. Thus, the Secretary had established a structure which, although idiosyncratic in its nomenclature, arguably conformed to the statutory requirements: major decisions would be made after full notice and hearing, and would result in an amendment to the Tomato Marketing Order; relatively minor implementing decisions, called "regulations", would be made without a formal hearing in accordance with current data about tomato production and prices.

In 1955 the Secretary amended the Tomato Marketing Order, after notice and hearing, to authorize the issuance of regulations that would "[1]imit the handling of tomatoes by establishing, in terms of grades, sizes, or both, minimum standards of quality and maturity." 108 Then, on several occasions during 1970, he issued regulations that not only limited marketing by sizes, but also created size differentials between "vine ripe" tomatoes and "mature green" tomatoes. Specifically, the regulations gave "mature greens" a 1/4inch advantage: the sale of "vine ripes" was prohibited if they were less than or equal to $217 / 32$ inches in diameter; "mature greens," on the other hand, could be sold as long as they exceeded $29 / 32$ inches. ${ }^{107}$

Plaintiffs, importers of Mexican tomatoes to whom the restrictions were also applicable, ${ }^{108}$ complained that the theory on which the differential was purportedly based-namely, that it would

${ }^{100} I d . \$ \S 608 \mathrm{c}(3)-(4)$.

${ }^{101}$ Id. $\S 608 \mathrm{c}(17)$ (1970), as amended, 7 U.S.C.A. $\S 608 \mathrm{c}$ (17) (Supp. 1974).

1027 C.F.R. Part 900 (1975).

${ }^{103}$ Id. $\S 900.8(\mathrm{~d})$. In practice, a witness is evidently permitted to limit his own crossexamination by refusing to answer questions he regards as irrelevant, personal, or repetitious. See Hamilton, supra note 40 , at 1296.

104 7 C.F.R. Part 966 (1975).

${ }^{105} I d$. $\$ 966.50-.56(1975)$.

108449 F.2d at 1013-14.

${ }^{107} \mathrm{Id}$. at 1013.

${ }^{105}$ See 7 U.S.C. § 608e-1 (1970), as amended, (Supp. 1971). 
equalize the burden of the restrictions among different classes of Florida growers-was unfounded in fact; that the differential imposed a discriminatory burden upon Mexican tomatoes and had been intended to do so; and that the statute precluded such a purpose. They also alleged that in view of the vague language of the 1955 amendment and the differences in circumstances since 1955, the Secretary should have permitted a hearing on the decision to impose differential size restrictions. The court of appeals decision, written by Judge Leventhal, ordered the district court to issue a declaratory judgment that plaintiffs were entitled to hearings, with some right of cross-examination, on "crucial" issues involved in tomato marketing control. After the decision, the Department held a five-week hearing featuring extensive cross-examination, and then reaffirmed its earlier decision. ${ }^{109}$ Parties disappointed by the decision are pressing for review of the regulation, on a wide variety of grounds. ${ }^{110}$

It is possible to construe the opinion as simply an interpretation of section 8c of the Marketing Act. Since that statute requires "notice" and "hearing" before issuance or amendment of a marketing order, the opinion might mean that an issue such as the $1 / 4$-inch differential can only be decided as part of the issuance or amendment of a marketing order, pursuant to the "hearing" mentioned in the Marketing Act. In this view, the decision has precedential effect only for other section $8 \mathrm{c}$ cases. But the opinion also invites a broader interpretation. Its tone, its lack of reliance on statutory history, and its focus on the nature of the decision-making process, the risks of industry domination, and the demands of basic fairness-all suggest that the decision was intended to reach further.

These broader possibilities of the case have had no perceptible impact at the Department of Agriculture: there have evidently been no similar claims for a hearing with rights of cross-examination; ${ }^{111}$ nor has the existence of the case prompted the Department to offer such hearings in any other instances where it previously would not have done so. ${ }^{112}$ The Department views the case as, at most, a correction of its momentary lapse from the principle that hearings

109 See 37 Fed. Reg. 17479 (1972).

"1" See Coast Marketing Co. v. Butz, Civ. No. $2154-72$ (D.D.C. filed Oct. 27, 1972); Consumers Union v. Butz, Civ. No. $2142-72$ (D.D.C. filed Oct. 26, 1972).

'11 Interview with R. Stanley Harsh, Deputy General Counsel, Department of Agriculture, in Washington, D.C., Aug. 22, 1974.

112 Id. 
are available on issues of the sort that were at stake in Walter Holm. ${ }^{113}$

\section{B. Federal Power Commission}

Nor have the hybrid rulemaking cases had any drastic impact upon the FPC. The two controversies in which the Commission was itself involved have not, as yet, involved any further agency proceedings. If the cases have had any other impact upon the Commission's behavior, the effects are subtle and apparently not onerous.

Prior to the rulemaking involved in Mobil Oil Corp. v. FPC, ${ }^{114}$ the Commission, in setting rates for transportation of natural gas, had customarily allocated to liquid and liquifiable hydrocarbon rates some portion of the pipeline's total costs. The allocation was independent of what the pipelines actually charged for transportation. The purpose behind this practice was to make sure that consumers of natural gas were not burdened with those costs. In February of 1968, the Commission issued a notice of proposed rulemaking, in which it declared that it was "contemplating adopting a statement of general policy"115 and then set forth the "general policy" in terms of suggesting a continuation of its existing practice. After a series of meetings with some of the interested parties, but without any hint that it proposed to set minimum rates for liquids and liquifiables in that very proceeding, the FPC issued an order doing just that. ${ }^{116}$

On review, the court first undermined one of the substantive premises of the order by holding that the Commission had no jurisdiction to set rates for liquid hydrocarbons. ${ }^{117}$ The court then reversed the FPC order as to liquifiables, because the Commission had allowed the original proceeding "to slide over into a proceeding fixing specific mandatory rates in which the required procedures, beginning with the notice of what was to be ultimately done by the Commission, were inadequate." 118 While declining to find FPC rate-

${ }^{113}$ Id.

II 483 F.2d 1238 (D.C. Cir. 1973).

115 See 33 Fed. Reg. 2860 (1968). See also 483 F.2d at 1243.

118 Order Establishing Charges for Transporting Liquids and Liquifiable Hydrocarbons, FPC Order No. 449, 37 Fed. Reg. 2954, 2957 (1972). Evidently, the justification for setting minimum prices, as opposed to merely making an accounting allocation, was that shippers of liquids and liquifiables would otherwise be able to use their market power to force the pipelines to agree to ship at lower rates; if this occurred, the FPC would have to raise transportation rates for natural gas in order to avoid impairing the financial position of the pipeline companies.

11483 F.2d at 1246-49.

$118 \mathrm{Id}$. at 1263. 
making governed by the formal rulemaking standards of sections 556 and 557, the court concluded that the procedures of section 553 alone were insufficient. It held that, because the Natural Gas Act made "substantial evidence" a prerequisite to judicial approval of the Commission's ratemaking decisions, the Commission must permit a "testing" of its evidence "by procedures sufficiently adversary in nature to provide a reasonable guarantee of its reliability." 119 The procedures were to include either cross-examination or some effective substitute, such as written questions to be answered either in writing or orally. ${ }^{120}$ Although the court of appeals, speaking through Judge Wilkey, relied heavily on the Natural Gas Act's requirements of substantial evidence and of a "record,"121 some of its languageparticularly that alluding to the need for a factual record that would make judicial review possible ${ }^{122}$ - seems applicable in any rulemaking case.

Since the decision, the FPC has, in its effort to prevent the costs of transporting liquids and liquifiables from burdening natural gas consumers, simply relied on its prior practice. ${ }^{123}$ It has not decided whether to resume the effort to set minimum rates for liquifiables. The Commission's General Counsel and Solicitor maintain that the procedural duties imposed by the court in Mobil Oil are essentially irrelevant both to the Commission's hesitation and to the ultimate decision on whether or not minimum rates should be pursued. ${ }^{124}$ Their view stems primarily from doubts that the technique the Commission employed in Mobil Oil was a genuine improvement over the existing practice anyway, and in part from a later decision of the District of Columbia Circuit, American Public Gas Association v. FPC (APGA), ${ }^{125}$ which in the opinion of the FPC has sharply limited Mobil Oil.

The second case involving the FPC, Public Service Commission, ${ }^{126}$ has also failed to result in any further FPC action. The case involved area ratemaking for the Texas Gulf Area, pursuant to the Supreme Court's approval of area ratemaking in the

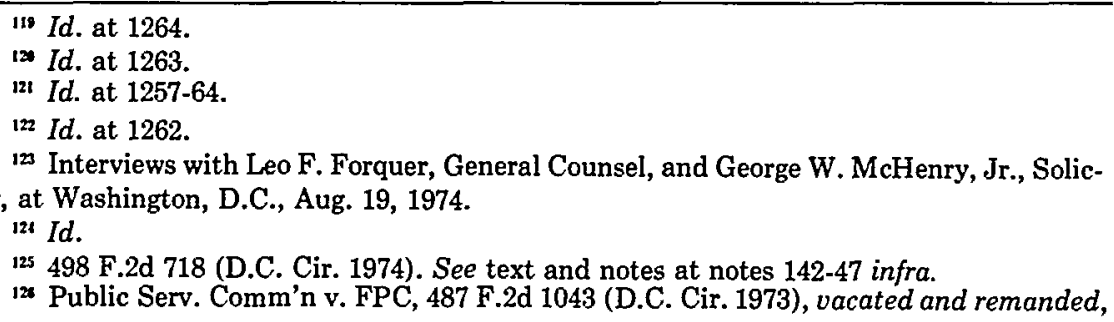
417 U.S. 964 (1974). 
Permian Basin Area Rate Cases. ${ }^{127}$ The Commission had established base rates and special provisions-"contingent escalations" and "refund work-offs"-purportedly designed to provide natural gas producers with additional incentives to explore and extract. ${ }^{28}$ The Commission relied upon the record in another area ratemaking proceeding, Southern Louisiana $I I,{ }^{129}$ as a source of factual support for the special provisions.

The court of appeals unanimously held that this reliance was improper "due to the lack of opportunity given to petitioners to respond to the incorporation of that record." through Judge Leventhal, the court underlined the potential significance of this lost opportunity by pointing to a series of claims by the challengers to which the FPC had made no response. ${ }^{131}$

As a legal basis for its conclusion, the court alluded to the statutory requirement of substantial evidence in the record, ${ }^{132}$ but its more fundamental premise appeared to be that the Commission had "not been responsive to petitioners' challenges to the incentive provisions of its rate order, and our judicial review function is thereby hampered."133 The decision was placed on grounds quite independent of the issue of how the ratemaking should be classified within APA categories; it so happened that the FPC had treated the matter as "formal" rulemaking, taking over 25,000 pages of testimony. ${ }^{134}$ Two members of the panel, Chief Judge Bazelon and Judge Richey, found the principle of the decision also applicable to the FPC's computation of base rates, saying that the Commission had failed to provide a "reasoned justification" of its solution, and had thereby made it "impossible for the parties to confront and challenge the bases for its actions." 135 They, too, stressed that a better record would be necessary if judicial review was to be more than "a formal rite of passage."136

\footnotetext{
${ }^{127} 390$ U.S. 747 (1968).

${ }^{128}$ For a discussion of the development of and statutory authority for the refund credit incentive, see Comment, Refund Beneficiaries and Refund Credits Under the Natural Gas Act, 41 U. CHI. L. Rev. 792, 807-13 (1974).

12. See Area Rate Proceeding (Southern Louisiana Area II), 46 F.P.C. 86, aff'd sub. nom., Placid Oil Co. v. FPC, 483 F.2d 880 (5th Cir. 1973), aff'd sub. nom., Mobil Oil Corp. v. FPC, 417 U.S. 283 (1974).

130487 F.2d at 1071.

131 Id. at 1071-79.

${ }^{132}$ Id. at 1069 .

135 Id. at 1080.

134 See Area Rate Proceeding (Texas Gulf Coast Area), 45 F.P.C. 674, 680 (1971).

135487 F.2d at 1098.

${ }^{136}$ Id. at 1099.
} 
Two Supreme Court decisions, and the passage of time, have rendered the case academic. In its review of the Southern Louisiana II rate proceeding, ${ }^{137}$ the Court in essence approved the base rate and special incentive devices that had been at issue in the Texas Gulf decision. ${ }^{138}$ This outcome alone would have suggested that any remand to the Commission, for the sort of procedure and articulation originally required by the court of appeals, would have had little effect. Moreover, the Supreme Court then vacated the judgment of the court of appeals in Public Service Commission and remanded the case to it for reconsideration in light of Southern Louisiana II. ${ }^{139}$ On reconsideration, the court of appeals denied the petitions for review. It relied largely on the circumstance that developments in the natural gas industry, such as the failure of natural gas dedications to reach the level necessary to trigger the special incentive provisions, had emptied the case of virtually all practical significance. ${ }^{140}$

Looking beyond the Mobil Oil and Public Service Commission controversies themselves, one can find little discernible impact at the FPC. For instance, in the Commission's most gigantic recent proceeding - the setting of national rates for certain natural gas sales-some of the parties demanded more elaborate procedures, citing Mobil Oil, and the Commission responded:

We believe that any question as to the adequacy of the procedures followed in this case that may have been raised by the Mobil Oil decision where [sic] laid to rest by the subsequent decision of the Supreme Court not to review the Phillips decision [in which the Tenth Circuit had approved the use of section 553 rulemaking for the purposes of the FPC's area ratemaking proceedings]. ${ }^{141}$ Moreover, the Court of Appeals for the District of Columbia Circuit has distinguished its holding in the Mobil Oil case in its holding that the Commission has the authority to establish initial rates by the use of rulemaking procedures. American Public Gas Association, et al. $v$. FPC. . . . ${ }^{142}$

137 Mobil Oil Corp. v. FPC, 417 U.S. 283 (1974).

13* In regard to base rates, compare $487 \mathrm{~F} .2 \mathrm{~d}$ at $1097-99$, with 417 U.S. at $315-21$; in regard to contingent escalations, compare 487 F.2d at 1068-77, with 417 U.S. at 321-27; in regard to refund work-offs, compare 487 F.2d at 1077-79, with 417 U.S. at 321-27.

139 FPC v. Public Serv. Comm'n, 417 U.S. 964 (1974).

1 to Public Serv. Comm'n v. FPC, 516 F.2d 746 (D.C. Cir. 1975).

IIt Phillips Petroleum Co. v. FPC, 475 F.2d 842 (10th Cir. 1973), cert. denied, 414 U.S. 1146 (1974).

1s2 FPC Op. No. 699, Dkt. No. R-389-B, Opinion and Order Prescribing Uniform National 
The Commission went on to cite the elements in Mobil Oil that the $A P G A$ court had relied on in distinguishing that case-the FPC's inadequate notice and its reliance on rather informal conference procedures. ${ }^{143}$

The quoted passage does not fully convey the Commission's concern about compliance with the basic thrust of the opinions in Mobil Oil and Public Service Commission. At other points in its national ratemaking opinion, the FPC stressed that its procedure permitted a meaningful dialogue between the parties and the Commission, ${ }^{144}$ and that none of the parties claiming a right to crossexamine had identified any issues requiring cross. ${ }^{145}$

The FPC's broader objectives may explain its long-run reaction to the two decisions. It has only recently embarked on the drastic step of abandoning its tedious procedures for ratemaking by means of formal rulemaking, in favor of section 553 procedures. The step received judicial sanction in Phillips and APGA, but in both cases the Commission's victory fell short of a carte blanche. In Phillips, the ratemaking had not yet taken place, and the court noted its power "to remand the cause to the agency for further delineation, information, or expression of views." 146 In $A P G A$, the court stressed that the Commission had provided all parties with an opportunity to criticize and analyze all the data and submissions on which it had relied; the court also emphasized the protesting parties' failure to identify any issues that could be explored more successfully by cross-examination than by the procedure actually employed. ${ }^{147}$ Thus, it is hardly surprising that the Commission has been able to take Public Service Commission and Mobil Oil in its stride. Providing parties advance access to its data and theories is a far less burdensome alternative than the procedures from whose tangles it appears to be escaping-including the virtually automatic right of all parties to engage in cross-examination.

Rate for Sales of Natural Gas Produced from Wells Commenced on or After January 1, 1973, and New Dedications of Natural Gas to Interstate Commerce on or After January 1, 1973, at 11 (June 21, 1974).

i4 Id.; see APGA, 498 F.2d at 723.

14 ". . . [E]very party has been given an opportunity to submit two sets of responses and replies to the responses of all other parties. Thus, no party can be heard to complain that he lacked an adequate opportunity to develop his case before the Commission." FPC Op. No. 699 , supra note 142 , at 14 .

145 "No party has pointed out any specific questions or issues that it would raise upon oral cross examination or why it could not adequately 'test, criticize, and illuminate the flaws in the evidentiary basis being advanced regarding a particular point' by other parties in its own written submissions. (See Mobil Oil Corp. v. FPC, . . .)." Id, at 12.

14875 F.2d at 850.

147498 F.2d at 723. 


\section{Environmental Protection Agency}

Of the agencies examined here, the EPA has made the most self-conscious effort to apply in new contexts the lessons of the hybrid rulemaking cases to which it has been a party: International Harvester, ${ }^{148}$ Appalachian Power, ${ }^{148}$ and Portland Cement. ${ }^{150}$ Its reactions are discussed in detail in the next section of this article. This section is limited to a resume of the EPA cases and their postremand history, together with a brief listing of the techniques adopted by the EPA in its effort at compliance.

In International Harvester, the EPA had denied the auto companies' applications, under the Clean Air Act of 1970, for one-year deferrals of the effective date of 1975 emissions standards. ${ }^{151}$ In remanding, the court of appeals imposed upon the EPA two procedural requirements: to permit "some opportunity for crossexamination," which the agency could confine "to the essentials, avoiding discursive or repetitive questioning"; ${ }^{152}$ and to provide the parties an "opportunity on remand to address themselves to matters not previously put before them by EPA for comment, including material contained in the Technical Appendix filed by the EPA in 1972 subsequent to its [original] Decision."'153

Again Judge Leventhal's opinion alluded to a statutory basishere, the Clean Air Act's requirement of a "public hearing." 154 But he invoked that requirement only in passing as a basis for the limited right of cross-examination and not at all as a basis for the broader right to see and challenge the critical steps of the EPA reasoning process. Against a background suggesting that the social costs of an erroneous refusal to suspend might be calamitous, ${ }^{155}$ and the court's clear feeling that the automobile companies had raised substantial doubts about the validity of the EPA's factual predictions, ${ }^{156}$ the court clearly put primary emphasis on its inability to

${ }^{14 \times}$ International Harvester Corp. v. Ruckelshaus, 478 F.2d 615 (D.C. Cir. 1973).

14 Appalachian Power Co. v. EPA, 477 F.2d 495 (4th Cir. 1973).

150 Portland Cement Ass'n v. Ruckelshaus, 486 F.2d 375 (D.C. Cir. 1973), cert. denied, 417 U.S. 921 (1974).

${ }^{151}$ See 42 U.S.C. $\$ 1857$ f-1(b) (5) (1970). Since the statute seemingly permitted reapplication after denial, there might have been a second hearing even in the absence of a remand. One might even speculate that the EPA was putting maximum feasible pressure on the auto companies by denying the first application while anticipating that it might later reverse itself.

152478 F.2d at 649. See also id. at 630-31.

153 Id. at 649 .

154 Id. at $629-31$.

${ }^{135}$ Id. at $636-38,641$.

15s Id. at 642-47. 
afford meaningful review if either right were denied. ${ }^{157}$

On remand, the agency substantially modified its decision, making it in many respects more lenient to the auto manufacturers. ${ }^{158}$ So far as cross-examination was concerned, the mandate of the court proved a shaggy dog story. Chrysler, which had vociferously insisted on the need to cross-examine, never once requested an opportunity to do so. And although Ford requested an opportuntiy to cross-examine the EPA staff members who had devised the methodology for the remand, ${ }^{159}$ it accepted the EPA's alternative offer of an off-the-record conference with those staff members. The EPA also furnished the auto companies with a fairly elaborate advance written statement of its proposed methodology.

The decision of the Fourth Circuit in Appalachian Power-the only one of these decisions rendered by a court other than the District of Columbia Circuit-involved similar procedural commands. At issue was the EPA's approval, under section 110 of the Clean Air Act, ${ }^{160}$ of "state implementation plans" for bringing ambient air pollution levels down to those prescribed by the Administrator under section 109 of the Act. ${ }^{161}$ Since the statute required each state to hold a hearing before adopting a plan, ${ }^{162}$ the court of appeals held that an EPA hearing could be dispensed with if, but only if, the state hearing had been "adequate." 163 The court's concept of adequacy was expressed rather vaguely:

What is required in all instances, whatever the character of the administrative action, is "the reality of an opportunity to submit an effective presentation," and, if in the context of the issues involved, "cross-examination on the crucial issues" is found proper, such right should be recognized and upheld. Walter Holm \& Company v. Hardin . . . . ${ }^{164}$

Again, one may summarize the case as requiring both a contingent right of cross-examination (though what it is contingent upon is obscure), and some opportunity for an effective challenge to the EPA's approach. To reach that result the Fourth Circuit relied nei-

${ }^{157}$ Id. at 632,649 .

${ }^{158} 38$ Fed. Reg. 10317 (1973).

159 Hearings on Applications for One-Year Suspension of the 1975 Motor Vehicle Emissions Standards 2182-86 [hereinafter cited as Emissions Suspension Remand Hearings].

${ }^{160} 42$ U.S.C. \$ $1857 \mathrm{c}-5$ (1970).

${ }^{161}$ Id. \& $1857 \mathrm{c}-4$.

${ }^{162}$ Id. \& 1857c-5(a)(1).

163477 F.2d at 502.

I6 Id. at 503. 
ther on APA classifications nor the substantive statute, but upon the necessities of judicial review. ${ }^{165}$ The court additionally alluded to due process considerations, ${ }^{168}$ but did not reveal just how the constitutional argument would run.

As was true in International Harvester, the contingent right to cross-examination was not exercised. Although the state hearings had not involved opportunity to cross-examine, ${ }^{167}$ the litigation concerning the implementation plans of West Virginia and Maryland ${ }^{168}$ was resolved by agreements under which the companies abandoned any claim to cross-examination. Instead the parties agreed that EPA would furnish a written response to each of the critiques made by the companies, to be followed by an opportunity for the companies to respond to the EPA response; and the companies would retain an option to call an off-the-record or on-the-record technical conference with the EPA. ${ }^{168}$

The mandate in Portland Cement is, of all the hybrid rulemaking cases the least detailed in its procedural prescription. Indeed, the court articulated its procedural demands as a functional appendage to its analysis of the challenger's substantive attacks on the agency's rule, which imposed air pollution performance standards on newly constructed Portland cement plants. After a discussion devoted principally to the challenger's factual contentions, the court declared: "This record reveals a lack of an adequate opportunity of the manufacturers to comment on the proposed standards, due to the absence of disclosure of the detailed findings and procedures of the tests." 170

Again speaking through Judge Leventhal, the court of appeals pointed to nothing in the substantive statute that might trigger any particular procedures. Instead, the court involked section 553 in a footnote: "Written comments were submitted as requested, and as

iss Id. at 503-07. The court explicitly assumed that the scope of review was whether EPA's action had been "arbitrary, capricious, an abuse of discretion, or otherwise not in accordance with law." Id. at 506-07, quoting APA § 10, 5 U.S.C. § 706(2)(A) (1970).

$168477 \mathrm{~F} .2 \mathrm{~d}$ at 503 .

167 Interview with Theodore L. Garrett, an associate at Covington \& Burling (Washington, D.C.), which is counsel for petitioners Appalachian Power Co., Duquesne Light Co. and Ohio Power Co., at Washington, D.C., Aug. 20, 1974.

148 The other dispute in the case-concerning Virginia's implementation plan-was resolved without the adoption of any formal procedure for exploration of factual contentions. Telephone interview with Neil T. Proto, attorney, Department of Justice, July 9, 1974.

is See stipulation dated June 20, 1974, in Appalachian Power Co. v. EPA, No. 72-1733 (4th Cir.); stipulation dated March 29, 1974, in Bethlehem Steel Co. v. EPA, No. 72-1776 (4th Cir.).

${ }_{170} 486$ F.2d at 402. See also id. at 392-95, 393 n.67 (reflecting failure of prior, unreported remand to cure problem of insufficient detail). 
required by the APA $\S 4(\mathrm{c}), 5$ U.S.C. $\S 553(\mathrm{c})$. Obviously a prerequisite to the ability to make meaningful comment is to know the basis upon which the rule is proposed."171 In the body of the opinion, moreover, the court justified the remand by relying upon the need for an adequate factual record that would enable it to discern whether, in the language of Citizens to Preserve Overton Park, Inc. $v$. Volpe, ${ }^{172}$ " the decision was based upon a consideration of the relevant factors and whether there has been a clear error of judgment." "173

The remand is complete, and the original rule, only slightly modified, has been affirmed on appeal. ${ }^{174}$ The EPA produced a 58page draft response, articulating its methodology and endeavoring to respond to critiques of the manufacturers that the court had deemed worthy of answer. Voluminous further critiques and a final EPA response followed. Although the challenger appealed, its brief did not launch any serious attack on the technical conclusions that had been the occasion of the remand. ${ }^{175}$

\section{The Utility of Cross-Examination}

Admittedly, it is impossible to discover exactly how much the various procedural devices ordered in the hybrid rulemaking cases have contributed to the elucidation of relevant issues. Even when new light dawns during cross-examination, for example, one can rarely say with confidence that some other procedure would not have shed equivalent light. The converse is also true: if examination fails to expose any material falsehood or inaccuracy, the reason may be that fear of cross-examination has inhibited a falsehood, has inspired exceptional caution, or has led to the witness's revealing on direct what might have been elicited on cross. In the language of social science, there is no "control group": no identical agency working on the same issue and following all the same procedures except the one whose value is being tested.

Nonetheless, our limited sampling is in some respects suggestive. Of the four cases in which some possibility of cross-

\footnotetext{
in Id. at 393 n.67.

172401 U.S. 402,416 (1971).

173486 F.2d at 402.

in Portland Cement Ass'n v. Train, 513 F.2d 506 (D.C. Cir. 1975).

${ }^{175}$ Brief of Petitioner Following Remand, D.C. Cir. No. 72-1073. The EPA staff counsel in charge of the matter believes that the remand not only produced a record that sufficiently supported the agency's rule, but also had (in conjunction with the other hybrid rulemaking cases) the long-term effect of inducing the EPA to base its rules on more adequate data. Telephone interview with Richard Denny, May 28, 1975.
} 
examination seemed to be required (Walter Holm, International Harvester, Appalachian Power, and Mobil Oil), Walter Holm is the only one in which it has actually occurred. Some indication of the role of cross-examination emerges from the challengers' brief and proposed findings of fact in that dispute, wherein they rely upon material brought out by cross-examination of witnesses who supported the proposed rule.

\section{A. Cross-Examination and Methodological Disputes}

By all odds the most dramatic instance of cross-examination cited by the challengers in Walter Holm was Louis F. Rauth's, a witness for the proponents of the $1 / 4$-inch differential. A key theory in support of the differential was that "vine ripe" tomatoes at the time of picking are approximately $1 / 4$-inch larger in diameter than "mature greens" at the time of picking. Rauth testified to field measurements of tomatoes which, he said, verified the differential. He spoke vaguely of making the measurements with his thumb and finger. ${ }^{176}$ During cross-examination the witness revealed that he had simply looked at the distance between his thumb and finger as they grasped the tomato, first when it was a mature green, and then, a week or so later, when he had returned to grasp the same tomato. In other words, he had used no instrument for measuring but his eyeball, and no method for recording the first measurement. Yet he claimed to have measured a $1 / 4$-inch growth. ${ }^{177}$

Had Rauth's "measurements" been the sole support for the alleged 1/4-inch differential, his cross-examination would presumably have demolished the proponents' case. One could fairly say that his testimony carried "its own death wound." 178 In fact, however, there was also substantial evidence of the more conventional statistical type, and material elicited on cross-examination had only a slight tendency to diminish the strength of that data.

The statistical evidence fell into two categories: formal reports of scientific sampling by agricultural experts, and records of the sizes of tomatoes actually shipped from Florida. Of the scientific reports, one, made in $1920,{ }^{179}$ indicated that Florida tomatoes displayed no growth in size worth mentioning in the last two weeks

176 Hearings With Respect to Proposed Amendment of Marketing Agreement and Order [hereinafter cited as Tomato Remand Hearings] at 217-18.

${ }^{177}$ Id. at 1654-55. Ironically enough, the pivotal questions were put by a representative of the Department of Agriculture.

17\% See NLRB v. Pittsburgh S.S. Co., 337 U.S. 656, 660 (1949).

13 Tomato Remand Hearings, Exh. 30. 
before becoming "vine ripe." In the week immediately preceeding that two week period, however, the tomatoes tested had shown an average growth of nine millimeters in diameter, well over a quarter of an inch. ${ }^{180}$ Thus, the issue of whether the 1920 report sustains or undermines the $1 / 4$-inch differential turns on the issue of how long before becoming "vine ripe" (a status shown by even a slight "blush" of pink on a tomato) mature green tomatoes are actually picked. If, but only if, such tomatoes are characteristically picked about three full weeks or longer before the "vine ripe" stage, the report tends to prove that the $1 / 4$-inch regulatory differential reflects a $1 / 4$-inch real-world differential.

The evidence on harvesting times relied on by the opponents of the rule consisted in part of statements by their own witnesses, but also included testimony by Florida growers who supported the differential. ${ }^{181} \mathrm{~A}$ concession from opposing witnesses certainly cuts more ice than the claims of one's own, so those concessions cannot be dismissed as mere duplications of the challengers' own direct evidence. Two circumstances suggest, however, that only limited value can be assigned to the challengers' having had a chance to cross-examine. First, the final decision was rendered by a Department of Agriculture official who was not physically present at the hearings; consequently, the concessions had no dramatic value so far as the ultimate decision making was concerned. Second, there seems no particular reason to suppose that well-drafted interrogatories (had they been permitted) would not have achieved as much.

The inferences drawn from the 1944 study are largely independent of any right of cross-examination. Although its methodology was not clear, it found an increase in the last four days before "vine ripe" status from 178.1 cubic centimeters to 193.4 cubic centimeters, or $8.59 \% .{ }^{182}$ Well established principles of mathematics permit one to convert a change in the volume of a sphere into the corresponding change in its diameter ${ }^{183}$ Cross-examination was hardly necessary, therefore, to show which side the 1944 report helped. Nor does

180 Id.

181 See id. at $47,51,1553,2269,3458$.

182 Although Exhibit 31, the 1944 report on tomatoes in Mississippi, speaks of measurements in cubic centimeters, the Department of Agriculture decision suggests that they may have been measurements of diameters. See $37 \mathrm{Fed}$. Reg. at 17482 . How this could be so is not immediately apparent.

${ }_{183} \mathrm{~V}=4 / 3 \mathrm{R}^{3}$ (where $\mathrm{V}$ is volume and $\mathrm{R}$ is radius). Thus, an $8.59 \%$ increase in volume equals a $2.8 \%$ increase in diameter; applied to a tomato of $29 / 32$ inches in diameter, it would mean an increase of about $2 / 32$, or only $1 / 4$ of $1 / 4$ of an inch. The mathematical implications of a given increase in volume, for purposes of ascertaining changes in diameter, are omitted from the Department of Agriculture decision. See id. 
it seem probable that cross-examination of those who prepared the 1944 study would have shed much light on the adequacy of its methodology.

In terms of identifying methodological errors, it would seem that the report's own omissions and revelations would provide a record to which cross-examination could add relatively little, because detailed articulation of methodology is presumably a prerequisite to scholarly acceptability. And in terms of determining the weight to be attached to methodological errors, although again concessions from the study's own creators would perhaps be ideal, interrogatories to the agency might achieve substantially similar impact. ${ }^{184}$

Further statistical evidence took the form of shipping data, especially for mid-January through April 1971. Data relied on by the Department showed that, as applied to vine ripes and mature greens shipped in that period, a 5/32-inch differential would have resulted in equality of withholding over that period. ${ }^{185}$ And once again, the challengers' attack on the Department's inferences drew little support from the fruits of cross-examination: (1) they maintained that the real issue was an 8/32-inch differential, the one recommended by the Florida Tomato Committee ${ }^{186}$ and adopted by the Secretary; 187 (2) they argued that equality of withholding between a "vine ripe" segment and a "mature green" segment of the Florida industry was probably not the true purpose of the proposed differential, because intentional production of vine ripes was trivial in Florida; ${ }^{188}$ and (3) they pointed to statistics suggesting the discriminatory impact on Mexican producers, and argued that the real-and illegal-motive was to achieve that impact. ${ }^{189}$ On matters of industry practices, particularly in connection with the second argument, concessions from Florida growers who favored the differential were somewhat useful. But again, it is not clear that live testimony sub-

${ }^{184}$ Cf. Robinson, supra note 24, at 522-23. Professor Robinson's argument that crossexamination forces "the agency to explain and articulate the assumptions and the foundations on which its policy rests" is true as far as it goes; but he suggests no reason to believe that (so far as most issues in most rulemaking proceedings are concerned) the same goal cannot be achieved as well by less time-consuming methods.

1s See 37 Fed. Reg. at 17483.

180 The Committee is comprised of Florida tomato growers appointed by the Secretary after nominations from the industry. It performs a variety of implementation functions under the Order. See 7 C.F.R. $\$ \$ 966.22-.35$ (1975).

${ }_{187}$ Brief of West Mexican Vegetable Distributors Association, December 23, 1971 (Department of Agriculture Dkt. No. A0-265-A3) at 53-57.

iss Id. at 49-52.

1 Id. at $19-26$. 
ject to cross-examination was much more useful than, say, interrogatories to the Department would have been (perhaps supplemented by affidavits of the challengers' own allies).

Taking the tomato dispute as a whole, then, it seems doubtful that the use of cross-examination was necessary to clarify either of the critical issues-the actual difference in size between "vine ripes" and "mature greens" at the times tomatoes are harvested, and the actual economic impact of the size restrictions. It is interesting that cross-examination scored its most dramatic hit when used to test an individual human being's visual measurements of tomato sizes. The Rauth testimony was fairly destroyed, so much so that one can hardly imagine an agency relying on his measurements in the slightest degree. 190 This observation tends to corroborate the assumption, commonly asserted in support of the hearsay exclusion, that cross-examination is valuable for challenging a declarant's perception. ${ }^{101}$ But the hit scored on crossexamination became rather like the proverbial punch into a bag of sand or grain; the mass reshaped itself, and little was changed. The case had been buttressed by enormous quantities of additional data -most of it ultimately resting on sense perceptions that could never have been subjected to cross-examination. In perspective, the one demolished sense perception proved to be of little importance. ${ }^{192}$

${ }^{180}$ The Department's final decision can be read to suggest that it did put some small stock in the testimony. See 37 Fed. Reg. at 17482.

${ }^{19}$ See, e.g., Morgan, Hearsay Dangers and the Application of the Hearsay Concept, 62 HaRv. L. Rev. 177, 188 (1948).

${ }^{192}$ Interestingly, a similar situation developed in the Portland Cement case, on an issue concerning which the court did not require cross-examination on remand. Ralph Striker, an engineer who specialized in kiln design, submitted an analysis of the EPA's test at the Dragon Cement Company's plant in Northhampton, Pennsylvania. By comparing the amount of $\mathrm{CO}_{2}$ going into the plant with the amount of $\mathrm{CO}_{2}$ the EPA had measured in the stack gases emitted, he was able to show that the figures relied on by the EPA violated the laws of chemistry. Portland Cement Ass'n v. Ruckelshaus, 486 F.2d 375, 397-98 (D.C. Cir. 1973); EPA Draft Response at 48-50 (Nov. 26, 1973); EPA Final Response, Appendix I at 12-14 (Nov. 1974). In its Draft Response on remand, the EPA conceded that a measurement error must indeed have been made, but argued that it must have been made in the measurement of particular chemicals in the stack gas (which would not undermine the test results), rather than, as Striker assumed, in the measurement of the stack gas flow rate. The argument is complex; happily, its merits are irrelevant to our inquiry. Even if Striker's contention had been accepted in full, it would have altered the data of only one test out of three at the Dragon Cement plant. The average test results from the Dragon plant would still have been well below the standard promulgated by the EPA. Moreover, the Dragon plant had been only one of six facilities tested. EPA Draft Response at 9-15, 48; EPA Final Response at 11-17, and Appendix I, at 12. It is hard to see how cross-examination of, say, the sloppy measurer could significantly alter the outcome.

The analysis presented here should not necessarily be limited to rulemaking. It would seem equally applicable to any "polycentric" problem-one in which many factors are rele- 


\section{B. Cross-Examination and Agency State of Mind}

The remand in Walter Holm also raised issues concerning the state of mind of members of the Florida Tomato Committee. ${ }^{193}$ The challengers contended that the Committee's purpose was to devise a regulation that would protect the Florida tomato industry from Mexican competition. Since the statute did not authorize that purpose, the Secretary's action in imposing the regulation might well have been struck down if an anti-import purpose had been found to have tainted his consideration. ${ }^{194}$ Since all parties apparently assumed that the circumstances presented an exception to the rule of Morgan $I V^{195}$ (which proscribes interrogation of administrators about their mental processes), the challengers vigorously crossexamined members of the Committee concerning their purposes. It so happened, however, that the challengers were in possession of the transcripts of tapes of the Committee's meetings. In view of the Committee members' fairly express proclamations on the tapes that they intended to protect Florida growers from Mexican competition, cross-examination could add little. The challengers were able to confront the Florida Tomato Committee manager and some of its members with statistical data that tended to draw in question their purported intention of "equalizing the burden," 198 and to rub their noses in the transcripts, ${ }^{197}$ but little more.

Granted, the presence of the tapes in Walter Holm was a happy fortuity. It seems quite probable that other instances will arise where Morgan IV's bar is lifted and where no such excellent substitute for cross-examination exists. But it should not be expected that circumstances of this kind are likely to result in a flowering of hybrid rulemaking. Normally, one supposes, it would be the court, rather than the agency itself, that would conduct such an inquiry. Walter Holm is probably an anomaly insofar as it involved an agency conducting an inquiry into the state of mind of its own

vant, their relationship and respective weighting is unresolved, and the amount of data supporting each factor is substantial. Licensing proceedings, for example, although classified as "adjudication," see 5 U.S.C. $\$ 551(6)-(7)(1970)$, would seem prone to the same difficulty.

193 On the nature of the Committee, see note 186 supra.

194 Citizens to Preserve Overton Park, Inc. v. Volpe, 401 U.S. 402, 416 (1971) ("To make this finding [that the Secretary's decision was not arbitrary, capricious or an abuse of discretion] the court must consider whether the decision was based on a consideration of the relevant factors . . . ."); Norwegian Nitrogen Prods. Co. v. United States, 288 U.S. 294, 31819 (1933). See also Friendly, Chenery Revisited: Reflections on Reversal and Remand of Administrative Orders, 1969 Duke L.J. 199, 209-17.

is United States v. Morgan, 313 U.S. 409 (1941).

198 See, e.g., Tomato Remand Hearings at 2994-3062.

in See, e.g., id. at 1597-99. 
appendage, the Florida Tomato Committee, in order to resolve the issue of whether its own decision making was tainted by defects in that appendage's state of mind. Customarily, by contrast, the need for inquiry into agency members' states of mind will not involve a court imposing procedures upon an agency, but simply a court employing its own traditional procedures directly.

Furthermore, insofar as there is a place for cross-examination at the agency in this regard, the rationale for it provides little basis for a more general expansion in hybrid rulemaking. The issue of the state of mind of agency members is quite different from the usual sort of fact issue in rulemaking. It does not involve extrapolation of data into the future, to determine whether the proposed rule will, as applied to real-world facts, have effects in accord with the agency's legislatively declared mandate. The concern is not in submitting data to rigorous analysis; it is in seeing how a few individuals will react when confronted with evidence that their public stance has been a facade. Thus, when agency state of mind is at issue, there is no thought that the agency members may save the rule by asserting a legislatively authorized value judgment; the whole problem is that they may have relied upon legislatively unauthorized values. In short, the circumstances that we previously identified as the peculiar characteristics of fact-finding for purposes of rule declaring are absent here. ${ }^{198}$

The Walter Holm setting should be distinguished from circumstances in which states of mind arise as a conventional issue within rulemaking. ${ }^{199}$ For instance, whenever a rule is to be promulgated because of its asserted deterrence value, it will be relevant to inquire whether the proposed rule will in fact have the desired effect on the behavior of those sought to be deterred. One may want to survey, for instance, the extent to which they are aware of existing penalties. ${ }^{200}$ But cross-examination of the people who are the subjects of the inquiry seems inherently infeasible, because it would consume extraordinary amounts of time and probably would add little to the survey itself. ${ }^{201}$

${ }^{188}$ See text and notes at notes $21-25$ supra.

199 In International Harvester there was a substantive state-of-mind issue, namely, whether Chrysler had shown compliance with the statutory prerequisite of making "good faith" efforts to meet the standards. 42 U.S.C. $\& 1857 f-1(b)(5)(C)$ (ii) (1970). EPA panel members vigorously cross-examined Chrysler executives on the point. On this issue, it would seem that the proceeding was indeed adjudicatory, because Chrysler's entitlement to a oneyear suspension turned upon its own good faith.

${ }^{200}$ See, e.g., F. Zimring \& G. Hawkins, Deterrence 145-47 (1973).

${ }^{201}$ Cf. Zippo Mfg. Co. v. Rogers Imports, Inc., 216 F. Supp. 670, 684 (S.D. N.Y. 1963). But cf. Wirtz v. Baldor Electric Co., 337 F.2d 518 (D.C. Cir. 1963) (persons who had filled in 


\section{Putting Cross-Examination into Perspective}

While the Walter Holm case simply fails to show that crossexamination is an effective investigative procedure in the rulemaking context, or even to suggest areas where imposing it upon an agency is likely to be efficient, the other hybrid rulemaking cases provide an even more telling indication of its value: they display parties trading away the right to cross-examination, or abandoning it without any offsetting benefit. In Appalachian Power, the challenging companies accepted a procedure that excluded crossexamination, and obtained, principally, a deferral of proceedings against them until completion of the EPA's review of the challenged state implementation plans. And in International Harvester, Chrysler thought it not worthwhile to exercise the right that it had so vociferously sought. ${ }^{202}$

In view of this circumstance, it should not be overlooked that a successful claim of a right to cross-examination offers challengers to a rule certain advantages that are independent of whatever elucidation it might furnish: First, and most obviously, crossexamination presents an opportunity for delay (except in the probably rare case when a court remands for a hearing involving crossexamination but leaves the rules in effect pending the hearing ${ }^{203}$ ). Second, possession of a right to cross-examination gives challengers a bargaining tool; by offering to waive the right, the challenger may be able to bargain for almost any benefit that the agency can bestow, including, presumably, a relaxation of the substantive standard. Third, the challengers' possession of a right to crossexamination may subtly exert pressure on the agency to take a milder stand, quite apart from explicit bargaining about relinquishment of the right. The milder the proposed rule, the more likely that the agency can completely escape the investment of resources that rulemaking through cross-examination techniques involves. Perhaps more important, the agency may be tempted to adopt the viewpoint of the challengers and thereby eliminate issues that would provoke extended cross-examination. Fourth, challengers may, by their treatment of witnesses, chill the readiness of scientists

a Bureau of Labor Statistics questionaire stated in affidavits that they had understood the questionaire to mean something different from what the Bureau was trying to derive from it). As for cross-examination of those who conducted the survey, an agency engaged in rulemaking would be interested not in their state of mind, but in their methodology.

${ }^{202}$ Mobil Oil is excluded from consideration because the matter has been wholly in limbo since the appellate court's decision. See text and notes at 123-25 supra.

${ }^{203}$ Cf. Portland Cement Ass'n v. Ruckelshaus, 486 F.2d 375 (D.C. Cir. 1973), cert. denied, 417 U.S. 921 (1974). 
to work for a regulatory agency. Rudeness and badgering, pedantry and sophistry will ultimately take their toll.204 Fifth, crossexamination of an unseasoned expert may score debating points whose value is more apparent than real. If, for example, a scientist has conducted an experiment and has omitted a particular precaution because of a reasonable judgment that the value of the precaution in assuring accuracy was outweighed by the effort necessary to employ it, the challenger may be able to make him appear as a knave or a fool. (One consolation, however, is that participation in research for rulemaking may ultimately breed a strain of scientists immune to this sort of cross-examination.) ${ }^{205}$

Apart from the leverage it gives challenging parties, crossexamination may actually tend to frustrate its own supposed goal: elucidation of the issues. Cross-examination virtually assures that high-level agency decision makers will not participate, for they do not have enough time for that sort of enterprise. For example, the hearing in Walter Holm took place before a "hearing examiner" without the power even to issue a recommended decision. By contrast, the inquiry conferences employed by the EPA in its emissions suspension case, and on the issue of flue-gas desulphurization, ${ }^{206}$ included substantial participation by the Administrator or his highest ranking assistants.

It may be that in other rulemaking contexts cross-examination would play a vital role in elucidating relevant issues. Certainly the cases described here represent too small a sample to establish the contrary proposition. Moreover, this sample may be biased by the presence of so many cases involving fact issues in the natural sciences or engineering. In such cases the crucial issues seem usually to be ones of methodology, and the history of scientific progress would suggest that cross-examination is not particularly efficient for resolving issues of that kind. Admittedly, the participants in traditional scientific controversy have stronger claims to being treated as impartial than the experts involved in most rulemaking. The former are usually not on the payroll of an organization with a large pecuniary or ideological stake in the outcome. Nevertheless, the struggle

${ }^{204}$ Cf. Hamilton, supra note 40, at 1290.

${ }^{203}$ Notwithstanding this list of factors, which are largely negative from an agency's point of view, it should be noted that on occasion agencies have more or less voluntarily tendered challengers an opportunity to engage in cross-examination. See Industrial Union Dep't, AFLCIO v. Hodgson, 499 F.2d 467, 471 n.9, 472 n.12 (D.C. Cir. 1974). Hindsight showed that the agency had had little to fear: "[t]he questions actually asked tended to be few, sporadic, and perfunctory. . . ." Id. at 471 n.9.

${ }^{208} \mathrm{See}$ text and notes at notes $237-46$ infra (on inquiry conferences). 
of scientists for the acceptance of their ideas, or for clarifications of accepted ideas, whether in the ivory tower or the context of decision making, seems to have advanced through relatively informal procedures. ${ }^{207}$

\section{Judicial Choices Concerning Cross-Examination}

1. Is it needed? The arguments advanced in this section of the article suggest certain conclusions about when a court should impose hybrid rulemaking through cross-examination and how it should be done. Given the questionable efficacy of crossexamination in the cases that have been surveyed, it would seem that courts should impose it only when the challenger has discharged the burden of doing at least the following:

First, he must identify with particularity the issues requiring cross-examination..$^{208}$ Only then can the court competently evaluate the claim. If the agency's record in the proceeding is too opaque for the court justly to put this burden on the challenger, a remand for purposes of clarifying the record may be in order.

Second, he must demonstrate the substantiality of the issues to be resolved by cross-examination. If resolution of them in accordance with the challenger's factual contentions would only trivially alter the data base for the agency decision, cross-examination would clearly be a waste. ${ }^{209}$

Third, he must demonstrate that less onerous procedures will probably not be able to resolve the issue with sufficient accuracy. For example, if sense perceptions are at stake, ${ }^{210}$ and were made by

207 The reasons advanced by Wigmore for the qualified exception to the hearsay rule for learned treatises seem relevant to reliance on uncross-examined evidence in this context: (1) necessity, because of the extraordinary inconvenience that would follow from throwing out all expert testimony not based exclusively on personal observation, and (2) trustworthiness, derived largely from the authors' interests in preserving and enhancing their reputations within the scientific fraternity. See VI Wigmore on Evidence $\$ \S 1691-92$ (3d ed. 1940).

As Judge Leventhal notes, dissenting in Cooper Labs., Inc. v. Comm'r, 501 F.2d 772, 793 (D.C. Cir. 1974),

... [A] particular case may involve the kind of issue that calls for an oral argument rather than an evidentiary hearing or for a legislative rather than an adjudicative hearing. These comments are highly pertinent when what is at issue are technical questions of methodology. Indeed, in such a case the reality of technical dialogue and interchange of view can perhaps best be provided by an on the record conference-hearing procedure, modeled on conference discussions between lawyers and experts. . . .

${ }^{208}$ For instance, there would have to be far more particularity than Chrysler's vague goal of cross-examining catalyst manufacturers in the emissions suspension case. See note 211 infra.

201 See text and notes at note 192 supra.

210 See text and notes at notes 176-78, 191 supra. 
persons not under the control of the challenger ${ }^{211}$ (or of a party with an interest identical to that of the challenger), the challenger can be said to have made out his prima facie case on this score.

2. Procedural Issues. Once the claim of a need for crossexamination has been favorably resolved, the court must face the issue of the proper forum: court or agency. As argued above, ${ }^{212}$ the principle of agency autonomy suggests a presumption in favor of remand to the agency. In some cases, Congress itself seems to have pointed the courts in precisely that direction. ${ }^{213}$ Other circumstances may point powerfully in the other direction. Sometimes, for example, the well-known exhortation not to put the fox in charge of the chicken coop may apply. If the challengers have made a showing sufficiently powerful to persuade a court that Morgan IV's

211 The International Harvester case points up the problem of identifying the parties with the best access to the underlying sense perceptions. In that case, it will be recalled, Chrysler made a passionate plea for the right to cross-examination, won it, and never used it. In the course of its plea, Chrysler had argued that the issue turned on the efficacy of catalysts, and that accurate resolution of the issue required that the auto manufacturers have an opportunity to cross-examine executives of the catalyst manufacturers. The difficulty with the argument was that in practice it was the auto companies who had best access to the relevant sense perceptions, since it was their employees who had done the testing. There had been some testing by Englehard Industries, but it had been relatively exceptional. See Emissions Suspension Remand Hearings at 915. See also id. at 969-70. In view of the auto companies' control over those who had conducted the testing and who therefore had made the relevant sense perceptions and transformed them into statistics, it is not surprising that, on this point at least, the auto companies backed away from their interest in cross-examination.

212 See text and note at note 96 supra.

${ }^{213}$ For example, section 19 of the Natural Gas Act provides that on review of FPC orders under the Act:

If any party shall apply to the courts for leave to adduce additional evidence, and shall show to the satisfaction of the court that such additional evidence is material and that there were reasonable grounds for failure to adduce such evidence in the proceedings before the Commission, the court may order such additional evidence to be taken before the Commission and to be adduced upon the hearing in such manner and upon such terms and conditions as to the court may seem proper. . . .

15 U.S.C. $\S 717 \mathrm{r}(\mathrm{b})(1970)$. See also Consumer Product Safety Act $\S 11(\mathrm{~b}), 15$ U.S.C. $\S$ 2060(b) (1972).

Language in the Administrative Orders Review Act, 28 U.S.C. $\S 2347$ (b) (1970), might seem to point the other way for remands of orders under its coverage (including certain final orders of the Federal Communications Commission, the Secretary of Agriculture, the Federal Maritime Commission, the Maritime Administration, and the Atomic Energy Commission). It provides that when an agency "has not held a hearing," and when, further, "a hearing is not required by law and a genuine issue of material fact is presented," the court "shall ... . transfer the proceedings to a district court. . . ." However, in view of the Supreme Court's decision in United States v. Florida E.C. Ry., 410 U.S. 224 (1973), treating a section 553 rulemaking as a "hearing" within the meaning of the Esch Act (see id. at 240), it would seem that a section 553 rulemaking cannot be regarded as one in which no "hearing" is required by law. On this interpretation, section 2347(b) is inapplicable and, if the Administrative Orders Review Act is relevant at all, section 2347(c), which contemplates remand to the agency for taking of additional evidence, would be the relevant provision. 
bar against inquiry into the agency's thought process should be lifted, it would ordinarily seem preferable that trial of the matter should proceed before a court rather than the agency. ${ }^{214}$

In a case in which trial de novo in court is more appropriate, there may be difficulties in locating a court. If the controlling statute provides for review in a court of appeals, but does not authorize transfer to a district court for resolution of factual issues, ${ }^{215}$ no clear route to a district court is evident. ${ }^{216}$ Section 703 of the APA provides for review in any court of competent jurisdiction in the event of "inadequacy" of the statutorily prescribed form of review; that condition is arguably present when there remains a factual issue whose resolution is essential for responsible substantive review, yet remand to the agency is inappropriate. Moreover, section 704 provides that "final agency action for which there is no adequate remedy in a court" is "subject to judicial review." In these circumstances, a challenger might be well advised to commence review proceedings at both levels-the statutorily prescribed petition to the court of appeals and a claim in the district court under the sections just mentioned. ${ }^{217}$ If the challenger fails to initiate a district court action, the present statutes do not readily suggest a way for the court of appeals to bring in the district court's adjudicatory skills.

Delicate problems of timing may arise as well. Because of recent relaxations of ripeness requirements, courts often engage in judicial review of rules prior to agency enforcement. But there may be a temptation to say, as the Sixth Circuit did in Buckeye Power, Inc. v. $E P A,{ }^{218}$ that any factual issues relating to the validity of the regulation should be deferred until the time of enforcement proceedings if the issues demand adjudicatory techniques. The conclusion seems too facile. The justification for easing ripeness requirements has been increased concern about the impact of the regulation upon

214 The court in Walter Holm was evidently too optimistic in its hope that ambiguities in the relationship between the tomato industry and the Secretary of Agriculture could be resolved, or at least rendered irrelevant, in hearings conducted before the Department with a right of cross-examination. Litigation inquiring into that relationship has not yet abated. See cases cited note 110 supra.

${ }^{215}$ Cf. 28 U.S.C. $\$ 2347$ (b)(3) (1970), discussed in note 213 supra.

216 A factual inquiry by the court of appeals is a conceivable alternative. See note 84 supra.

${ }^{217}$ Some basis for jurisdiction would also, of course, be necessary. In circuits recognizing sections 702,703 , and 704 as jurisdictional grants, the search would be easy, at least if the arguments in the text are accepted. Elsewhere, an independent basis of jurisdiction would be necessary. For a recent summary of cases on the issue, see Pickus v. United States Bd. of Parole, 507 F.2d 1107 (D.C. Cir. 1974).

${ }_{213} 481$ F.2d 162, 173 (6th Cir. 1973); cf. Verkuil, supra note 64, at 204. But cf. Getty Oil Co. v. Ruckelshaus, 467 F.2d 349, 355-356 (3d Cir. 1972). 
the conduct of affected industries prior to the moment of any enforcement proceedings ${ }^{219}$ (and, perhaps, lessened concern that a court should not speak to an issue until the imminence of civil or criminal penalties makes judicial review-if it is ever to occuran immediate necessity). But the impact upon industry conduct is not limited or qualified merely because the validity of the regulation turns upon as yet unresolved factual issues. At most, the inconvenience occasioned by the need for some cross-examination should be an element to be weighed when the court considers the ripeness issue. Once the court has found that the regulation is ripe for judicial review, however, there would seem to be extraordinary awkwardness in trying to determine its validity without regard to the factual problems, leaving their resolution to another day. Such a bifurcation can rarely satisfy the interests of either side. To be sure, Congress's allocation of review jurisdiction between the district courts and the courts of appeals may mean that the courts are reduced to a Hobson's choice-between the inconvenience of bifurcation on the one hand and that of trial direct by the court of appeals or its reference to a master on the other. ${ }^{220}$

\section{The Utility of Procedures Less Onerous Than Cross- EXAMINATION}

Attention must now be directed at the three methods that the EPA has employed in its effort to assure challengers of its rules a meaningful "opportunity to participate" in the rulemaking process: (1) an advance written statement of methodology; (2) an inquiry conference, on- or off-the-record; and (3) written agency answers to interrogatories. In a way it is a pity to have to itemize them into categories, for one gets the impression that it is the deft meshing of the devices that is most effective in complying with the spirit of the hybrid rulemaking cases. Nonetheless, it seems necessary to distinguish among them in order to describe them.

\section{A. Written Statements of Methodology}

In at least four cases, the EPA has tried to furnish (or has committed itself to furnishing) a clear statement of its methodology well in advance of any final agency action, thus permitting detailed criticism. These instances include the remands in International

219 Abbott Labs. v. Gardner, 387 U.S. 136, 152 (1967); cf. Vining, Direct Judicial Review and the Doctrine of Ripeness in Administrative Law, 69 MicH. L. REv. 1443, 1502-04 (1971).

220 See cases cited at note 84 supra. 
Harvester, ${ }^{221}$ Appalachian Power, ${ }^{222}$ and Portland Cement, ${ }^{223}$ and the EPA's entire process for promulgating effluent limitations guidelines under the Federal Water Pollution Control Act. ${ }^{224}$ In Appalachian Power, the process has begun fairly recently, pursuant to the stipulations by the parties. In Portland Cement, the EPA's draft engendered extensive comment, but its final statement in essence reaffirmed the original standards. The challengers again sought judicial review, but in doing so they virtually abandoned the technical arguments that had been the occasion of the remand, preferring instead to press constitutional claims that the court of appeals had already rejected. ${ }^{225}$ The court of appeals affirmed the standards per curiam. ${ }^{228}$ This history suggests that the remand performed its intended function. ${ }^{227}$ It is an open question, however, whether it would have accomplished as much in the absence of an appellate opinion pinpointing what the court perceived as material substantive gaps. The International Harvester and effluent limitations instances require more extensive discussion.

Shortly before the public hearing on remand in International Harvester, the EPA made available to the auto companies a fortyeight page statement of its proposed methodology. The statement essentially mooted one of the auto companies' major criticisms of the first proceeding-namely, that the agency's failure to analyze the data in terms of "engine families" invalidated its results. ${ }^{228}$ The challengers had advanced two arguments against that omission. First, EPA procedures for certifying the manufacturers' production lines did proceed engine-family-by-engine-family; consequently, the omission had highlighted the agency's failure to link the reasoning by which it concluded that the manufacturers did not need an extension to the criteria by which it would later grant or deny certification to produce autos. Because each engine family presents a unique pollution problem, awareness of such a link had been impor-

221 Pursuant to court direction, International Harvester Corp v. Ruckelshaus 478 F.2d 615, 631-33, 649 (D.C. Cir. 1973).

${ }_{222}$ As a result of settlement stipulations, Appalachian Power Co. v. EPA, 477 F.2d 495 (4th Cir. 1973); see text and note at note 169 supra.

223 Pursuant to court direction, Portland Cement Ass'n. v. Ruckelshaus, 486 F.2d 375, 392-95, 402 (D.C. Cir. 1973), cert. denied, 417 U.S. 921 (1974).

22438 Fed. Reg. 21202 (1973).

${ }^{225}$ See Brief of Petitioner Following Remand, D.C. Cir. No. 72-1073.

226 Portland Cement Ass'n v. Train, 513 F.2d 506 (D.C. Cir. 1975).

22 See note 175 supra.

228 Joint Supplement to Briefs of Petitioners General Motors Corp., Chrysler Corp. and Ford Motor Co. 6-8, 10-11; Ford Motor Co. Brief 33-35; Ford Reply Brief 7-11. Note that, even apart from the directions from the court, the process of litigation itself may have constituted part of the dialogue between the auto companies and EPA. 
tant to the companies. Second, the omission had made it impossible to develop any theory for predicting what portion of the nation's total 1975 auto demand could be satisfied if 1975 standards were not suspended. ${ }^{229}$ Issuance of the EPA's proposed methodology resolved the entire issue, and, by articulating definitions of the various engine families, made it possible for the controversy to move to more refined issues: details of the process of making predictions for each engine family. Later, when EPA staff and auto company technicians met in Ann Arbor in an off-the-record conference, the proposed methodology provided a starting point for discussion..$^{230}$

Another example of how the EPA's announcement of its methodology on remand led to fruitful criticism was the agency's adoption of the "Monte Carlo" statistical technique. On remand, the EPA asked the manufacturers to submit proposals for the methodology to be used, and the Monte Carlo method was suggested by General Motors. ${ }^{231}$ The method permits one to transform data that varies on a random basis into usable predictions. For example, in different tests of the same car, emission levels vary randomly. ${ }^{232}$ By means of the Monte Carlo method, it is possible to derive a figure indicating the maximum emission level for cars of that type with a ninety-five percent probability of accuracy. ${ }^{233}$ The technique thus made it possible for the agency to comply with the appellate court's demand that its predictions have demonstrable "statistical reliability."234

The EPA's device for promulgating effluent limitation guidelines under the Federal Water Pollution Control Act represents a systematic transformation of rulemaking into a two-round process, instead of the single round minimally required by section 553. Prior to its initial notice of proposed rulemaking, the EPA makes available to any interested person a technical analysis of the issues, prepared by private consultants under contract with the EPA. Public comments on these drafts are solicited, and only afterwards does the EPA promulgate its proposed rule. Simultaneously with the notice of proposed rulemaking, it publishes its own draft report trying to substantiate the proposed rules. ${ }^{235}$ Agency personnel did

229 Cf. 478 F.2d at $640-41$.

230 Telephone interview with Thomas Austin, EPA staff, Oct. 1, 1974.

21 See Technical Appendix to EPA Administrator's April 11, 1973 Decision, at 38.

${ }^{232}$ Id. at $38-40$.

233 Of course, this confidence level assumes the accuracy of the data and the soundness of all other aspects of the methodology.

234 478 F.2d at 648; see the use of figures in the Administrator's April 11, 1973 decision, 38 Fed. Reg. at 10323.

${ }^{235}$ See 38 Fed. Reg. 21202-06 (1973). 
not describe this procedure as a product of the hybrid rulemaking cases ${ }^{236}$ although the agency's adoption of the procedure may reflect its internalization of the norm imposed in those cases. From the agency's point of view, the process is not a burden but simply an efficient way of carrying out its substantive mandate. ${ }^{237}$

\section{B. Inquiry Conferences}

What I have called the "inquiry conference" has figured in a variety of EPA proceedings: the International Harvester case, both originally and on remand; the agency's "hearing" on flue-gas desulfurization ("FGD"); and the agency's promulgation of effluent guidelines under the Water Pollution Control Act for the pulp and paper industry and for the steam electric power industry.

The agency's original hearing on the auto companies' application for a one-year suspension of standards represented something of an innovation. Speakers for affected companies and interest groups delivered statements, and were subjected to questions from the members of the EPA panel, which sometimes included the Administrator and almost always the Assistant Administrator for the Office of Enforcement and General Counsel. In addition, everyone in the audience was free to submit written questions to mem-

${ }^{236}$ E.g., interview with Robert V. Zener, Deputy General Counsel, at Washington, D.C., Aug. 19, 1974. One EPA lawyer expressly denied that the procedure was in any way attributable to the line of cases analyzed in this article. Interview with G. William Frick, at Washington, D.C., Aug. 21, 1974.

237 The EPA declared in its announcement of the proposed procedures: "EPA believes that the exposure of the technical basis and reasoning underlying regulations to be established pursuant to sections $304(\mathrm{~b}), 306$ and $307(\mathrm{c})$ is essential to the promulgation of sound effluent limitations guidelines and standards of performance for new sources." 38 Fed. Reg. at 21202.

The FAA, the CAB, the FPC, and the ICC, and perhaps other agencies, have (both before the earliest and after the latest of the hybrid rulemaking cases) employed an "Advance Notice of Rulemaking" to achieve what amounts to two rounds of notice and comment. See, for example, FAA notices published at 39 Fed. Reg. 45044 (Dec. 30, 1974); 39 Fed. Reg. 11193 (Mar. 26, 1974); 39 Fed. Reg. 5785 (Feb. 15, 1974) (initiating a process called "First Biennial Airworthiness Regulations Review," promulgating a schedule contemplating final adoption of any resulting amendments in February 1976 and providing not only for two full rounds of notice and comment but also for conferences to elucidate issues); 38 Fed. Reg. 14757 (June 5, 1973); and CAB notices published at 37 Fed. Reg. 15518 (Aug. 3, 1972); 36 Fed. Reg. 20309 (Oct. 20, 1971); and 36 Fed. Reg. 2514 (Feb. 5, 1971).

The two rounds of notice and comment initiated by these advance notices should be distinguished in purpose from the two rounds that were initiated by the EPA in the water effluent guidelines context. For the EPA, the focus was on assuring a full canvass of complex scientific, technological, and economic issues. In the FAA and CAB notices, however, the agency has sketched out an area under consideration, suggested some issues that ought to be resolved, and called for comment in a very openended fashion. The FAA-CAB two-round process is thus less sharply tailored to the resolution of complex methodological issues. 
bers of the panel, who would then usually put the question or its substance to the speaker. Counsel for Ford Motor Company and for the Natural Resources Defense Council were the most active submitters of questions. In the remand hearing, which followed the same procedure, one such question hit extraordinary paydirt: in response to a question from the NRDC lawyer, a representative of Engelhard Industries (a catalyst manufacturer) testified that Chrysler executives had told him that they were refusing to buy catalysts from Engelhard in order to punish the company for its testimony in the original hearings. ${ }^{238}$ Chrysler escaped denial of suspension only because the economic consequences of selective denial were so drastic; EPA felt virtually bound to find "good faith" unless confronted with absolute proof of its absence. ${ }^{239}$

In addition to the public hearings on remand, the EPA arranged for an off-the-record conference in Ann Arbor on technical methodology. At this meeting, auto company experts were able to state in detail their objections to the proposed methodology, and the EPA technical staff were able to respond. Substantial modifications were made as a result of the meeting. ${ }^{240}$ The style of the meeting was relatively informal, featuring more rapid-fire, spontaneous giveand-take than was characteristic of the hearings before the EPA panel.

The other inquiry conferences amounted to variations on the above themes. The conference on effluent guidelines for the pulpand-paper industry, called by the EPA in response to pressure from industry representatives, was largely dominated by speeches by industry spokesmen. Although the industry participants were invited to put questions to the agency technical staff, ${ }^{241}$ they chose not to do so. The agency technical staff questioned them closely, on the other hand, probing the theories behind their complaints. ${ }^{242}$ Thus, by choice of the industry representatives, the conference did nothing to clarify agency reasoning for them. In similar hearings in connection with steam electric power plants, however, industry representatives used their opportunity, so that the flow of questioning went both ways. This conference, like the Ann Arbor meeting, constituted

${ }^{238}$ Emissions Suspension Remand Hearings at 982-95, 1020-40.

239 See 38 Fed. Reg. at 10327-330.

210 Telephone interviews with William F. Pedersen, EPA staff attorney, and Thomas Austin, EPA technical staff, Oct. 1, 1974.

${ }^{241}$ Technical Meeting-Effluent Limitations Guidelines for Pulp, Paper and Paperboard Manufacturing Point Source Category and Builders Paper Board Manufacturing Point Source Category, April 4, 1974, at 8-10.

${ }^{212}$ Id., passim. 
the EPA's alternative to the cross-examination right demanded by industry. ${ }^{243}$ Unlike the Ann Arbor meeting, it was on-the-record.

The FGD hearings were unique in that they were aimed not at making a "rule," but at policy-making in a broader sense. The report that emerged from the conference produced recommendations in three categories: (1) recommendations addressed to the utility companies, in essence exhorting them to get cracking; (2) recommendations addressed to the EPA itself and to the states, urging them to direct a variety of carrots and sticks toward the utilities; and (3) recommendations relating to the sequence and pacing of compliance schedules to be developed by negotiation between the utilities, the states, and the EPA. ${ }^{244}$ The hearing was not viewed as a means of conforming to the mandates of the hybrid rulemaking cases, but rather as a catalyst for resolution of some fundamental policy issues at a high executive level. ${ }^{245} \mathrm{As}$ in the auto emissions suspension hearings, an EPA panel presided. Here the flow of questions went in every direction: from the EPA panel to industry representatives and to EPA technical experts; from EPA technicians to industry technicians, and the reverse; and even from industry representatives to other industry representatives.

At least from the EPA's point of view, the FGD hearing was a sound investment of time. Although the EPA did not lose its basic belief in the efficacy of FGD, the hearing did persuade high-level EPA personnel of the reality of several utility industry problems: (1) the greater readiness of state regulatory commissions to allow utilities to pass through the costs of switching to low-sulfur fuel, on the one hand, than to permit similar pass-throughs of FGD installation costs, on the other; (2) the seriousness of the problems relating to FGD malfunctions and the need to reassure the power companies that malfunctions would not impose substantial risks of noncompliance penalties; and (3) the industry's difficulties in trying to achieve the designated goals within the time spans proposed by EPA. ${ }^{246}$

${ }^{213}$ Counsel for the Utility Water Act Group, George Freeman, indicated in a telephone interview that EPA's conduct up through the inquiry conference was consistent with its duties under the International Harvester case, notwithstanding the absence of cross-examination. September 10, 1974.

244 Report of the EPA Hearing Panel, National Public Hearings on Power Plant Compliance with Sulfur Oxide Air Pollution Regulations [hereinafter cited as FGD Report] 9-10 (January 1974).

${ }^{215}$ Interview with Richard Wilson, Director, Division of Stationary Source Enforcement, EPA, at Washington, D.C., Aug. 22, 1974.

216 Id.; FGD Report at 8-9, 63-65. 
Are these conferences more effective on- or off-the-record? Each alternative has the defects of its virtues. The off-the-record approach makes it possible for participants to be less cagey, more open, and better able to focus upon the search for truth; by the same token, it offers the anxious participant little or no assurance that he has pinned the other side down to any position. The calculus for the on-the-record conference presents a mirror image. Resolution of the issue must turn on particular facts. ${ }^{247}$

\section{Interrogatories}

The third discrete device is to send interrogatories to the agency. This approach was employed by counsel for the steam electric power plants in connection with the setting of effluent limitations guidelines. Its desirability depends on the comparative advantages of written as against oral questioning. Again, each seems appropriate in its place. Relying on written questions is timeconsuming and the answers are inevitably labored; and, to be effective, the device may require follow-up in the form of additional interrogatories or oral questioning. The conference approach, on the other hand, permits rapid exchange of questions and ideas, but with the risk that statements will be made clumsily and will leave what in hindsight appears to be a murky record.

\section{The Judicial Role}

Although we saw a number of doctrinal difficulties that may arise when a court seeks to implement a challenger's right to crossexamination in rulemaking proceedings, courts should have few problems inducing agencies to adopt hybrid rulemaking procedures like the ones discussed in this section. Probably the style of remand typified by Chenery $I$ offers a satisfactory framework. The premise in all "hybrid rulemaking" cases is that the challengers have raised questions about the agency's substantive action that are so serious that the agency must justify its position more adequately than it has. This is the essence of a Chenery-type remand, which affords an agency an opportunity to identify whatever links it purports to find between its action and its substantive mandate. The distinctive feature in the cases now under discussion is that the inadequacy of the agency's explanation results from its failure to have made it

217 Note that the stipulations settling Appalachian Power gave the choice between an onthe-record or off-the-record conference to the challengers of the rule. See text and note at note 169 supra. 
possible for the challengers to identify and critique its methodology earlier in the proceedings. ${ }^{248}$ It would not seem a material extension of Chenery if the court, in ordering such a remand, were to point out the problem. The agency would then be on notice that if it again failed to give the challengers an adequate opportunity to critique it in advance, it would only be exposing itself to the risk of yet another round: not because of its failure to adhere to any particular procedure, but because its reasoning would still appear insufficient in the face of the challengers' factual contentions. Thus, a court can assure that issues are aired sufficiently for it to perform its function of substantive review, without impinging upon the ability of the agency to select the procedural devices that appear most suitable in light of the substantive issues involved and the agency's institutional capacities.

\section{CONCLUSION}

In closing, it is appropriate to point out the aspect of the hybrid rulemaking cases that seems to enjoy the greatest capacity for growth. All the features of cross-examination that set it apart from "normal" rulemaking procedural techniques have made it seem-deceptively, I suggest-particularly attractive to the courts that have found "notice-and-comment" inadequate in four of these cases. When the relatively modest role of cross-examination on remand is examined, the attractions are diminished. What emerges as more vital, and certainly more readily susceptible to frequent application, is the principle of assuring challengers timely access to the critical reasoning processes of the agencies.

In making that access real, the cases have helped to generate a series of flexible devices: double rounds of notice-and-comment; conferences with varying degrees of formality; and agency answers to interrogatories. Although for many rulemaking proceedings the use of even one of those devices might be overkill, for others-where decisions of dramatic economic or social impact are at stake-they represent useful tools for disciplining agency action without entan-

24x But cf. South Terminal Corp. v. EPA, 504 F.2d 646 (1st Cir. 1974), reviewing the EPA's Metropolitan Boston Air Quality Transportation Plan. The court noted that a need for further hearing arose out of the petitioners' failure to present to the EPA the data that they had presented to the court. Thus the defect arose from petitioners' "fault," but the court justified its imposition of a burden on the EPA by noting the importance of the subject to the public at large. Id. at 666 . This article has not analyzed the South Terminal case in detail, because the hearing on remand was to be conducted under the same ground rules that the EPA had applied originally. Thus, the case did not impose new procedural standards on the EPA; it was simply a remand for more of the same. 
gling it in elaborate procedures. Whether a court should ever mandate the use of any particular device seems doubtful. But the courts may insist that the "opportunity to participate" afforded by section 553 be meaningful; and they may demand that agencies develop a record that enables a reviewing court to find an intelligible answer for each substantial challenge posed. ${ }^{249}$ Under these judicial pressures, agencies should be able to work out the detailed procedures most suitable to each specific task.

${ }^{248}$ For recent discussion of the problem of establishing a "record" for purposes of noticeand-comment rulemaking, see Recommendation 74-4, 1973-74 REPORT OF THE ADMINISTRATIVE CONFERENCE of THE UNITED STATES 58; Pedersen, Informal Ruelmaking at the Environmental Protection Agency, to be published in a forthcoming issue of Yale L.J. (title may differ). See also Texas v. EPA, 499 F.2d 289, 321-22 (5th Cir. 1974), in which Judge Clark, concurring, noted: "No formal hearing has ever been held in this highly technical, factually complex matter. The administrative 'record' upon which we had to base our review was comprised of only the sparest of documentation, for it essentially evolved from an act of agency rulemaking ...." 